\title{
RUHA (URFA) HANLARI ÜZERINE BIR DEĞERLENDIRME
}

\author{
ADIL ÖZME
}

Urfa şehir merkezinde, tamamını ya da bir kısmını koruyup, günümüze kadar gelebilen 11 şehiriçi hanı bulunmaktadır. Ayrıca bugün mevcut olmayan hanlardan, hava fotoğrafları ve kaynaklardan yararlanılarak 13 tanesinin isimleri saptanmış, yerleri lokalize edilmiş (Harita: 1 ) ve 5 tanesinin de tarihleri tespit edilmiştir.

Bu hanlardan 20 adedinin, bir avlulu olarak inşa edildiği saptanmıştur. Hanların çoğunluğunda avlu kare veya dikdörtgen planlı iken, Aslanlı Han (1649'dan önce), Kumluhayat Hanı (en geç 19. yy), Mençek Hanı (18. yy. başı), Hacı Kamil Hanı(1823), Millet Hanı (17. yy.'in 2. yarısı ile 18. yy.'in sonu arasında) ve Topçu Hanı (1903) avluları yamuk planlı olarak düzenlenmiştir (Plan: 1-10, Resim: 1-5, Tablo: 1).

Urfa hanları kat sayılarına göre tek kath, kısmen iki kath, iki kath ve kısmen üç katlı olmak üzere, kendi aralarında dört gruba ayrılır (Tablo: 1).

Tek katlı hanlardan yalnızca Samsat Kapısı Hanı (1600-1649 tarihleri arası), Millet Hanı ve Kumluhayat Hanı günümüze gelebilmiştir. Tek kath olarak düzenlenmiş şehiriçi hanlarından, 1432 tarihli Bergama Taş Han'ı ile Balat'daki Menteşeoğulları Dönemi'ne ait iki hanı, Beylikler Dönemi örnekleri olarak verebiliriz ${ }^{1}$. Bugüne kadar yapılan arașurmalar, Osmanlı Dönemi'nde tek katlı ve avlulu plan tipinde inşa edilmiş hanlardan Tire Çöplü Han (1426-1442) ${ }^{2}$, Gaziantep Hişva Hanı (16.yy.) ${ }^{3}$, İzmir Sulu Han (en geç 1671) ${ }^{4}$ ve Pocitel'deki Şişman İbrahim Ağa (İbrahim Kethuda) Hanı'nın (16. yy. ortaları $)^{5}$ mevcut olduğunu göstermektedir. Oldukça az örneği görülen tek

${ }^{1}$ A. Baş, " Beylikler Dönemi Hanlarında Uygulanan Plan Șemaları", 9. Milletlerarası Türk Sanatlanı Kongresi, 23-27 Eylül 1991, Bildiriler, C. III, Ankara 1995, s.278.

${ }^{2}$ M. Özer, Tire'de Ticaret Yapıları, (A.Ū. Sosyal Bilimler Enstitüsū, Arkeoloji ve Sanat Tarihi (Sanat Tarihi) Anabilim Dalı, Yaymmlanmamış Yüksek Lisans Tezi), Ankara 1992, s.54-59.

${ }^{3}$ F. Öztürk, Gaziantep Hişva Hanı va Anadolu Hanı, (A.Ü. Dil ve Tarih-Coğrafya Fakültesi, Arkeoloji ve Sanat Tarihi Bölümü, Yayınlanmamıs Lisans Tezi), Ankara 1994, s.23-24, Resim: 122.

${ }^{4}$ B. Ersoy, İmir Hanlan, Ankara 1991, s.11-13.

${ }^{5}$ E. H. Ayverdi, Avrupa'da Osmanl Mimari Eserleri, Yugoslavya, C. II, Istanbul 1981, s.152. 
katlı ve avlulu hanlardan, Urfa'da bugün üç hanın günümüze gelmiş olması önemlidir.

Urfa'da kısmen iki katlı hanlardan iki örnek bulunmaktadır. Bu plan tipi, bir katlı hanlardan iki kath hanlara geçiş tipi olarak değerlendirilebilir. Topçu Hanı'nın batı kanadı üzerinde yan yana sıralanmış, avlu cephesine segment kemerli birer kapı ve pencere açıklığı ile bağlanan odalar, yapının kısmi ikinci katını oluşturur. 1900 tarihli Bican Ağa Hanı'nda ise, güney cepheden bir kapı açıklığı ile kısmi ikinci kata ulaşılır. Kitabesinde misafirhane olarak belirtilen bu katın, bugün yalnızca duvarlarının bir bölümü ayakta kalabilmiştir. Bu plan tipin örnekleri olarak İzmir Girid Hanı (18.yy) ${ }^{6}$, Gaziantep Yüzükçü Hanı (1800-1801) ${ }^{7}$, İzmir Arab Hanı (19.yy'ın 2.yarısı) ${ }^{8}$, Birecik Sabunhane (en geç 1890) ${ }^{9}$ ve Belediye Hanı (1896-1897) ${ }^{10}$ sayllabilir. İzmir Arap Hanı, İzmir Girid Hanı ve Birecik Sabunhane'de ikinci kat, giriş cepheleri üzerinde yer alırken; Topçu Hanı'nda ikinci kat, Birecik'teki Belediye Hanı'nda olduğu gibi bat kanat üzerinde yer alır. Gaziantep Yüzükçü Hanı'ndaki kısmi ikinci kat, güney ve batı kanatta olup L planlıdır.

Urfa hanları içerisinde en büyük grubu bir avlulu ve iki kath hanlar oluşturur.

Bugün tamamen yok olan Aslanlı Han ile Mençek Hanı, Hacı Kamil Hanı, Şaban Hanı (1703 tarihinden önce) ve Şark İşhanı (1907) bu plan tipinin örnekleridir. Tire Lütfü Paşa Hanı (16.yy) ${ }^{11}$ Gaziantep Yeni Han $(1757-1785)^{12}$, İzmir Mirkelamoğlu Hanı (18.yy'ın son çeyreği $)^{13}$, Manisa Yeni Han (1860-1862) ${ }^{14}$, Gaziantep Elbeyli Han (19.yy. sonu) ${ }^{15}$ benzer örnekler olarak verilebilir ${ }^{16}$.

${ }^{6}$ B. Eisoy, a.g.e., s.50-51.

${ }^{7}$ M. Özkarcı, "Gaziantep'te Dört Han”, Vakıflar Dergisi, C. XXVI, Ankara 1997, s.276-277.

${ }^{8}$ B. Ersoy, a.g.e., s.47-50.

${ }^{9}$ C. Kürkçüoğlu, 1996, s.75-76 S. Gündüz, "Hanlar”, Birecik, Halfeti, Suruç, Bozova İlçeleri ile Rumkale'deki Taşınmaz Kültür Varhkları, (Ed. A. Durukan), Ankara 1999, s.127-129.

${ }^{10}$ S. Gündüz, a.g.m., s.121-126.

${ }^{11}$ M. Özer, a.g.e., s.76-84.

${ }^{12}$ N. Güngör, Gaziantep Elbeyli Hanı ve Yeni Han, (A.Ü. Dil ve Tarih-Coğrafya Fakültesi, Arkeoloji ve Sanat Tarihi Bölümü, Yayımlanmamış Lisans Tezi), Ankara 1995, s.25-29.

${ }_{13}$ B. Ersoy, a.g.e., s.30-35.

14 1. Kuyulu, Kara Osmanoğlu Ailesi'ne Ait Mimari Eserler, ( A. Ü. Sosyal Bilimler Enstitüsü, Yayınlanmamış Doktora Tezi), Ankara 1988, s.76-88.

${ }^{15}$ N. Güngör, a.g.e., s.16-24.

${ }^{16}$ Sınıflandırma için bkz. B. Ersoy, "Osmanlı Şehiriçi Hanları, Plan Tasarımı ile Cephe ve Malzeme Özellikleri”, Sanat Tarihi Dergisi, VII, İzmir 1994, s.75-97. 
Urfa'da, bir avlulu ve kısmen üç katlı hanlardan iki örnek bulunmaktadır. 1563 tarihli Gümrük Han'ın, doğu cephesindeki giriş açıklığının üzerinde yer alan mescidin iki yanında, asma kat olarak inşa edilen üç oda, kısmi üçüncü katı oluşturur. Barutçu Han'da (17.yy sonu-18.yy başı) ise, bugün kuzey ve batıdaki ayakta, doğu kanatta izleri saptanabilen $\mathrm{U}$ şeklinde üçüncü kat yer alır. Bu kat, önde bir koridor ve bu koridora açılan farklı büyüklükteki düz ahşap tavanlı odalardan oluşmaktadır. Bu plan tipinin benzer örnekleri olarak Merzifon Taş Han (17.yy) ${ }^{17}$ ve İstanbul Kalcılar Hanı (18.yy) ${ }^{18}$ gösterilebilir. Merzifon Taş Han'da, kuzey kanat alt katta yer alan ahır kısmından; İstanbul Kalcılar Hanı ise, eğimli bir arazide inşa edilmesi nedeniyle, kısmen üç katlı olarak düzenlenmiștir.

Urfa hanlarında yolcuların/tüccarların kaldıkları ya da büro olarak kullandıkları mekanların genellikle revakların gerisinde, avluyu tek sıra halinde kuşattıklarını görürüz. Yalnızca Gümrük Han'da farklı bir düzenleniş görülür. Üst katta doğu ve kuzey kanat, dış cephede yer alan dükkanlar nedeniyle geniş tutulmuştur. Bu yüzden kanatlarda yer alan mekanlar, birer kapı ve pencere açıklığı ile, birbirine bağlı ikişer oda şeklinde düzenlenmiştir. Benzer uygulamalara Diyarbakır Deliller Hanı (1527) ve Hasan Paşa Hanı'nda (1574-1575) da ${ }^{19}$ rastlanır. Deliller Hanı'nın dıştan sadece bat cephesinde dükkan dizilerine yer verilmişken, Hasan Paşa Hanı'nda tüm cephelerde dükkan dizileri yer alır. Bu nedenle Deliller Hanı'nda yalnızca batı kanatta, revak gerisine birbirine birer kapı açıklı̆ı ile bağlı ikişer oda yerleştirilmişken, Hasan Paşa Hanı'nda ikinci kat revakları gerisinde yer alan mekanlar, bütün katta birbirine bağlı iki oda şeklinde düzenlenmiştir ${ }^{20}$.

Urfa hanlarının çoğunda revak gerisinde yer alan mekanlar, revaka birer kapı ve pencere ile bağlanırken, istisnai durumlara da rastlanır. Samsad Kapısı Hanı'nda avlu çevresinde bağımsız mekanlara yer verilmemiştir. Bu yapı, Antalya-Korkuteli yolundaki Evdir Han'da $(1210-1219)^{21}$ görülen planın 17. yy. da yeni bir tekrarı niteliğindedir .

${ }^{17}$ S. Erken, Türkiye'de Vakuf Abideler ve Eski Eserler, C. 1, Ankara 1983, s.323-325.

${ }^{18}$ C. Güran, Türk Hanlarının Gelişimi ve İstanbul Hanları Mimarisi, İstanbul 1978, s.123124.

${ }^{19}$ Bkz. M. Sõzen, Diyarbakur'da Türk Mimarisi, İstanbul 1971, s.193-199.

${ }^{20}$ B. Ersoy, "Dıyarbakır Deliller Hanı", Kültür ve Sanat (Diyarbakır Özel Sayısı), Sayı:28, Ankara 1995, s.21-23; E. E. Bay, Diyarbakır Hanlan, (A.Ü. Dil ve Tarih-Coğrafya Fal'ültesi, Arkeoloji ve Sanat Tarihi Bölümü, Yayınlanmamış Lisans Tezi), Ankara 1990, s.1-17.

${ }^{21}$ I. İtler, Tarihi Türk Hanlan, Ankara 1969, s.20. 
Hanlarda, mekanlar bazen de eyvan şeklinde düzenlenmiştir. Mencek Hanı alt kat batı kanadında; sıralı olarak bir eyvan bir mekan şeklinde düzenleme yapılmışken; Şaban Hanı üst kat güney kanatta yer alan mekanlar tümüyle eyvan şeklinde düzenlenmiştir. Aynı düzenlemeye Kumluhayat Hanı'nda da rastlanır. Hanın avlu kuzeybat kanadı, Şaban Hanı'nda olduğu gibi eyvan dizisi şeklinde düzenlenmiştir. Benzer bir uygulamaya da Gaziantep Belediye Hanı (1885-1886)'nda ve Kilis Andibendioğlu Ali Efendi Hanı (1905)'nda rastlanır. Belediye Hanı'nda, güney kanatta avluya açılan eyvanlara yer verilirken ${ }^{22}$; Andibendioğlu Ali Efendi Hanı'nda ise, güneydeki kanatta çapraz tonoz örtülü hole açılan, batı yöndekiler daha dar olarak inşa edilmiş, karşılıklı dörder eyvan bulunmaktadır ${ }^{23}$.

Şaban Hanı'nda dikkat çeken diğer bir durum ise, üst kat güney kanatta yer alan revakların önünde geniş bir terasın bulunmasıdır. Alt katta bulunan ahırın geniş tutulmasından dolayı üst katta böyle bir zorunluluk doğmuştur. Benzer bir düzenleme de 1698-1699 tarihinde inşa edilen Amasya Taş Han'da uygulanmıștur ${ }^{24}$. Burada üst katun doğu, batı ve kuzey kanatları, dış cephede yer alan dükkanlardan dolayı geniş tutulmuş, bu nedenle revakların önünde, Şaban Hanı'nda olduğu gibi geniş teraslar oluşmuştur. Bu teraslardan doğu ve batıdakinin ortasına birer, kuzeydekine de iki mekan yerleştirilmiştir ${ }^{25}$.

Urfa hanların içerisinde, plan tasarımı açısından dikkati çeken bir han da Kumluhayat Hanı'dır. Hanın avlu güneybatı kanadında, ortada büyük bir eyvan ve yanlarda iki mekan şeklinde bir düzenleniş görülmektedir. Anadolu hanlarında rastlanmayan bu düzenlenişe, Suriye hanlarında rastlamaktayız. Halep'teki 1516 tarihinden sonra inşa edilmiş Kurt Bey Hanı'nda da benzer bir düzenleniş görülür. Söz konusu hanın batı kanadında Kumluhayat Hanı'nda olduğu gibi bir eyvan ve iki mekan şeklinde bir düzenleniş görülmekte$\operatorname{dir}^{26}$.

${ }^{22}$ M. Özkarc1, a.g.m., s. 275-312.

${ }^{23}$ A. Dündar, Kilis'teki Osmanlı Dönemi Mimari Eserleri, Ankara 1999, s.380-381.

${ }^{24}$ B. Ersoy, "Osmanlı Şehiriçi Hanlarından Ōnemli Bir Örnek: Amasya Taş Han", 9. Milletlerarası Türk Sanatlan Kongresi, İstanbul 23-27 Eylül 1991, Ankara 1995, s.81-92.

${ }^{25}$ B. Ersoy, a.g.m., s. 81-92.

${ }^{26}$ A. Raymond, Osmanlı Dönemi Arap Kentleri, (Çev. Ali Berktay), İstanbul 1995, s.174183, plan:19. 
Urfa hanlarında dikkati çeken diğer bir uygulama Barutçu Hanı, Topçu Hanı ve Bican Ağa Hanı'nda görülmektedir. Bu hanlarda, üst katta yer alan kısmi ikinci veya üçüncü katlara, avlu kanatlarında yer alan merdivenlerin dışında, dış cephelerden de bir veya iki kapı ile geçiş sağlanmıştur. Bu uygulamanın diğer örneklerine Birecik Sabunhane'de ${ }^{27}$ ve Kilis Andibendioğlu Ali Efendi Hanı'nda ${ }^{28}$ rasthyoruz. Bu yapılarda da üst katta yer alan ikinci katlara, dış cephede yer alan bir kapı açıklığı ile çıkış sağlanmıştır.

Urfa hanlarında ahır/develik, avlu kanatlarına yerleștirilmiştir. Gümrük Hanı, Mencek Hanı, Barutçu Hanı, Millet Hanı'nda ahır bir veya iki kanadı kaplarken; Hacı Kamil Hanı'nda alt kat, kitabesi bulunmayan ve Candaroğlu İsmail tarafindan yapurıldığı belirtilen Kastamonu İsmail Bey Hanı'nda olduğu gibi ${ }^{29}$, bütünüyle ahır olarak düzenlenmiştir. Şaban Hanı dışındaki bütün hanlardaki ahırlar, Tire Çöplü Han ve Kutu Han'da (1429) olduğu gibi, revaklarla avluya açılırken, Şaban Hanı'ndaki ahır, bir kapı açıklı̆̆ ile avluya bağlanmaktadır.

Anadolu şehiriçi hanlarında oluşturulan mescit; yapıların alt katında, üst katında veya avlu ortasında olmak üzere üç şekilde görülürken ${ }^{30}$, Urfa hanları içerisinde bugün yalnızca Gümrük Han'da mescit bulunmakta ve üst katta girişin üzerinde yer almaktadır. Gümrük Hanı'nda olduğu gibi, Diyarbakır Deliller Hanı'nda ${ }^{31}$, Tire Kutu Han'da ${ }^{32}$, Ankara Çengel Han (15221523) 'da ${ }^{33}$ ve Kastamonu Yanık Han'da (17.yy sonu-18.yy.başı) ${ }^{34}$ mescidler, giriş eyvanının üstünde yer almaktadır. Sonradan yapılan onarım ve değişiklikler, diğer Urfa hanlarında mescit kısmının yerini tespit etmemize olanak vermez.

Urfa hanlarından sadece Barutçu Han'da tuvalet mekanı görmekteyiz. Burada, alt katın güney kanadında revakların arasında yer alan segment ke-

${ }^{27}$ S. Gündüz, a.g.m., s.127-129.

${ }^{28}$ A. Dündar, a.g.e., s. $380-381$.

${ }^{29}$ Z. K. Bilici, Kastamonu'da Türk Devri Mimarisi ve Șehir Dokusunun Gelişimi (18. Yüzyıl Sonuna Kadar). (A.Ü. Sosyal Bilimler Enstitüsü, Yayımlanmamış Doktora Tezi), Ankara 1990, s. 116. şek. 61 .

${ }^{30}$ B. Ersoy, a.g.m. 1994, s.84.

${ }^{31}$ E. E. Bay, a.g.e., s.1.

${ }^{32}$ M. Özer, a.g.e., s.60-67.

${ }^{33}$ B. Ersoy, a.g.m. 1994, s.84.

${ }^{34}$ Z. K. Bilici, a.g.e., s.271-297. 
merli kapı açıklığı ile girilen ve bugün de tuvalet olarak kullanılan küçük mekanın, orijinalde de tuvalet olarak kullanıldığı düşüncesindeyiz.

Şadırvan ise, bugün yalnızca Hacı Kamil ve Mençek Hanı'nda görülmek tedir. Ancak, yapılan onarımlarla orijinal durumlarını tamamen yitirmişlerdir.

Urfa hanlarında taşıyıcı sistemleri duvar, ayak, sütun, konsol ve destek kemerleri oluşturur (Tablo: 1).

Duvarlar, taşıyıcı duvar ise, kesme taş kaplamalı moloz dolgulu duvar olarak; perde duvar ise, kesme taş olarak inşa edilmiştir. Taşlar arasında bağlayıcı harç olarak küfeki taşı tozu, kireç ve su karışımından elde edilen "kül kireç" denilen harç kullanılmıştur ${ }^{35}$.

Sütun sadece Barutçu Han ve Mençek Hanı'nın ikinci kat revaklarında, revak kemerlerini desteklemek amacıyla kullanılmışur. Her iki yapıda da sütunlar eş yükseklikte, aynı çapta ve monobloktur. Başlıklar her iki yapıda da, kesik koni şeklindeki bir alt bölüm üzerinde, köşeleri yuvarlatılmış kare prizma formludur. Sütunlar Mençek Hanı'nda doğrudan kare prizma formlu altlıklar üzerine otururken, Barutçu Han'da kare prizma kaide üzerine profilli bir bilezikten sonra oturmaktadır. İzmir Kızlarağası Hanı(1744) ${ }^{36}$, Mirkelamoğlu Hanı ${ }^{37}$, Diyarbakır Hasan Paşa Hanı ve 16.yüzyıla tarihlenen Çifte Han'da da, avlu revaklarında Urfa örneklerimizde olduğu gibi sütun kullanılmıştır ${ }^{38}$ (Tablo: 1 ).

Paye en fazla tercih edilen taşıyıcı elemandır. Revak köşelerinde daha iri boyutlu L, kare ve dikdörtgen payeler tercih edilirken, revak cephelerinde yer alanlar dikdörtgen formludur. Bu payeler Millet Hanı, Topçu Hanı, Hacı Kamil Hanı, Gümrük Hanı revak köşelerinde ve Şaban Hanı'nın ahır bölümü tonozlarını destekleyen iki payede olduğu gibi, adeta fil payeler şeklindedir (Tablo: 1).

Konsol, Gümrük Hanı'nın doğu cephesinde, girişin üzerinde yer alan mescit duvarının kuzey ucunda, saçaklarda ve birinci katın revaklarının üzerinde; Barutçu Han'ın üçüncü kat merdivenlerinin altunda ve Bican Ağa Ha-

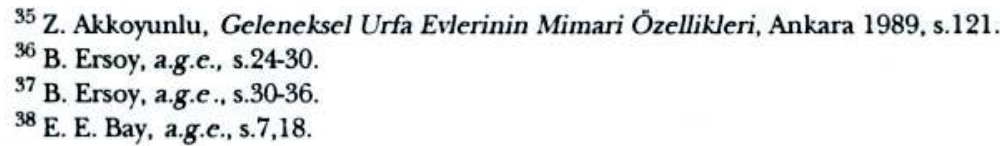


nı'nın güney cephesinde ikinci kata çıkan giriş açıklığının üzerindeki çıkmada kullanılmıştır. Diğerlerinde sade bir özellik görülürken, Bican Ağa Hanı'nda üç konsol dizisi, üç kademe yaparak yükselmekte ve uçlanı bezemelerle sonlanmaktadır. Benzer konsollara Urfa evlerinde de sıkça rastlanır ${ }^{39}$.

Kemer revaklarda, kapı ve pencere açıklıklarında, nişlerde, portal kavsaralarında ve tonozları desteklemek amacıyla kullanılmıştur. Kemer tipi olarak yarım daire, sivri, kaş, dilimli, segment ve sepet kulpu tercih edilmiștir. Urfa hanlarından sadece Şaban Hanı ahır kısmı ve Hacı Kamil Hanı alt kat köşe mekan tonozlarında destek amacıyla kullanılmıştır. Revaklarda daima sivri kemer tercih edilmiştir. Tek istisnai örnek Şaban Hanı'dır. Burada, revaklarda ilk yapı döneminde sivri kemer, sonraki bir dönemde yapılan onarımlarda ise, yarım daire kemer kullanılmışur. Kaş kemer, Gümrük Hanı mescidinin doğu cephesindeki orta pencere alınlığı kuşatma kemerinde, üst kat doğu ve kuzey kanatlarında ard arda inşa edilen ikili mekanların ara duvar pencerelerinde kullanılmıştur. Dilimli kemer, yine Gümrük Hanı mescidi doğu cephesinde yer alan pencere alınlıklarında üç dilimli, Millet Hanı portal kuşatma kemerinde beş dilimli, Millet Hanı örtü sistemine çıkışı sağlayan kapı ve Barutçu Hanı üçüncü kat avlu cephesindeki orta pencerede çok dilimli olarak uygulanmıştır. Sepet kulpu kemer, yalnızca Hacı Kamil Hanı üst kat bat revakı gerisindeki mekanların kapı ve pencerelerinde karşımıza çıkar (Tablo: 1).

Urfa hanlarında örtü sistemi olarak tonoz, ahşap tavan ve çatular ile, düz salma taş örtü kullanılmıştur.

Tonoz olarak beşik tonoz ve çapraz tonoz tercih edilmiştir. Beşik tonoz yalnızca Topçu Hanı'nın avluya giriş holü üzerinde ve Şaban Hanı'nın kuzey ve doğu revaklarındaki ikinci dönem onarımlarında kullanılırken; diğer hanlarda sivri beşik tonoz tercih edilmiştir. Sivri beşik tonozdan sonra en fazla tercih edilen tonoz tipi, çapraz tonozdur. Geleneksel Urfa evlerinde ${ }^{40}$ ve diğer anıtsal yapılarda da bu tonoz tipleri sıkça kullanılmıştır ${ }^{41}$.

${ }^{39}$ Z. Akkoyunlu, a.g.e., s.161-162.

${ }^{40} \mathrm{Z}$. Akkoyunlu, a.g.e.

${ }^{41}$ M. Alper, Urfa'nun Mekansal Yapısı Türk-Islam Mimarisindeki Yeri, (İ.T.Ü. Fen Bilimleri Enstitüsũ, Yayımlanmamıs Doktora Tezi), İstanbul 1987, s.10-56; C. Kürkçüoğlu, Sanluurfa Camileri, Ankara 1993. 
Ahşap tavan ve çatılar, Barutçu Han'ın üçüncü katı ve Topçu Hanı'nın ikinci katındaki mekanların tavanlarında içte düz örtü, dışta ise beşik çatı şeklinde görülür. Benzer uygulamalar Birecik Çifte Han ve Belediye Hanı ${ }^{42}$ ikinci kat mekanlarının örtü sisteminde görülmektedir. Her iki yapıda da üst kat odalarının üzeri ahşap tavan ile örtülmüştür. Ayrıca, Çifte Han üst kat odaları, Topçu Hanı'nda olduğu gibi ahşap direklerle taşınan bir sundurmaya açılmaktadır ${ }^{43}$. Ahşap örtü kullanımı daha çok Gaziantep hanlarında yaygındır. Kentte Elbeyli Hanı hariç, diğer bütün hanların üst kat revaklarının üzeri, alttan ahşap kirişlemeli düz tavan, üstten kırma kiremit çatı ile örtülüdür ${ }^{44}$.

Barutçu Hanı'nın ikinci kat revaklarının örtüsünde ve Mençek Hanı'nın ikinci kat bat, güney ve kuzey revaklarının örtüsünde düz salma taş örtü kullanılmıştur. Erken uygulamalarına Erzurum Çifte Minareli Medrese (13. yy. sonu) eyvan önü ${ }^{45}$ ve Korkuteli Sinaneddin Medresesi (1319) ${ }^{46}$ kuzey ve güney yöndeki revaklarda rastladığımız bu örtü sistemi, çok tercih edilmemiştir.

Pencereler düşey dikdörtgen şeklindedir. Aslanlı Han, Gümrük Han ve Şaban Hanı'nda avlu cephesindeki pencereler düz atkı taşı ile örtülürken, Gümrük Hanı'nda sonraki ilavelerde segment kemerli pencereler kullanılmıştur. Bu yapılar dışındaki tüm hanlarda avlu cephelerinde, segment kemerli pencere açıklıkları tercih edilmiştir. Ancak, avlu cephelerinde segment kemerli pencereler kullanılırken, dış cephe pencerelerinde düz atkı taşlı pencereler daha çok yer almaktadır. İstisnai iki örnek Şark İs Hanı ve Barutçu Han'dır. Şark İş Hanı'nda bütün pencereler segment kemerli iken, Barutçu Hanı'nın yalnızca giriş cephesi ikinci ve üçüncü kat pencereleri segment kemerlidir. Düz lentolu ve segment kemerli pencereler dışında, Barutçu Han'ın üçüncü kat avlu cephesi ortasında yer alan pencerede dilimli kemer; Gümrük Hanı'nın üst kat kuzey ve doğu kanatlardaki mekanları birbirine bağlayan pencerelerde ise, kaş kemerler kullanılmıștır. Bu pencereler dışında, Gümrük Han'ın alt kat avlu revakları arasında örülen geç dönem duvarlarında, kapı ve pencerelerin üzerinde yer alan rozet pencereler

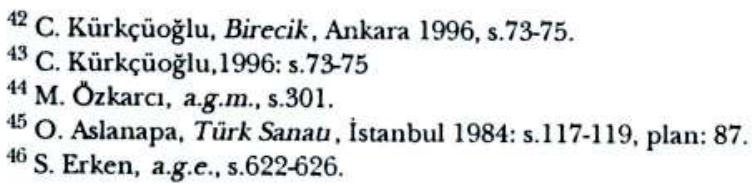


(havalandırma takaları) hem hava sirkülasyonunu hem de ışıklandırmayı sağlayan ögelerdir. Madalyon șeklinde olan bu pencerelerin benzerleri Urfa evlerinde de çok sık kullanılmışur ${ }^{47}$.

Kapılar ana giriş kapıları ve mekan kapıları olmak üzere iki grupta incelenebilir. Gümrük Hanı, Hacı Kamil Hanı ve Şaban Hanı'nda biri daha küçük olmak üzere iki giriş kapısı bulunmaktadır. Bu kapılar, beşik tonozlu kavsaralara sahip segment kemerli açıklıklar şeklindedir. Diğer yapılardan farklı olarak, yalnızca Millet Hanı'nın portal kuşatma kemeri beş dilimli olarak tasarlanmıștur.

Giriş açıklıklarındaki kapı kanatları, kalın ahşap tahtaların yan yana getirilip, arkadan iki ya da üç kuşağa büyük çivilerin yardımıyla tutturularak oluşturulur. Bunlanın üzeri kimi örneklerde sac ile kaplanmıştur. Mekanlanı avluya ya da revaklara bağlayan kapılar, küçük boyutlu olarak tasarlanmıştur. Yaklaşık olarak $90 \times 185 \mathrm{~cm}$. boyutlarındaki bu kapıların üzerinde Gümrük Han, Aslanlı Han ve Şaban Hanı'nda olduğu gibi, düz lento ya da diğer örneklerde olduğu gibi segment kemer tercih edilmiştir.

Gümrük Hanı dışındaki tüm örneklerde,saçaklar bir veya iki profilli dışa hafif taşkın, enli saçaklardır. Yalnızca Gümrük Hanı dış cephe saçakları küçük konsol dizisi üzerine oturmaktadır. Benzer saçaklar, Behram Paşa tarafindan Gümrük Han ile beraber 1563 tarihinde Urfa'da yapturılan Dabakhane Camii ${ }^{48}$ ve Diyarbakır Deliller Hanı'nda da görülür ${ }^{49}$.

Günümüzde yalnızca üç handa korkuluk kullanıldığı tespit edilmiştir. Aslanlı Han, Hacı Kamil Hanı ve Gümrük Han'ın revaklarının taş malzemeden, zikzaklı forma sahip korkuluklarla çevrildiği anlaşılmaktadır (Şekil:1). Bu tip korkuluklara Urfa'da sivil mimarlık örneklerinde de rastlanı ${ }^{50}$.

Bugün yalnızca dört yapıda çörten görülür. Samsat Kapısı Hanı'nın avlu cephelerinde yer alan çörtenler kısa, küçük oluklar şeklinde iken; Aslanlı Han, Gümrük Han ve Hacı Kamil Han'da daha uzun olup adeta stilize edilmiş aslan başı formu verilmiştir. Bu tipte çörtenlere Suriye'deki hanlarda da rastlanmaktadır ${ }^{51}$.

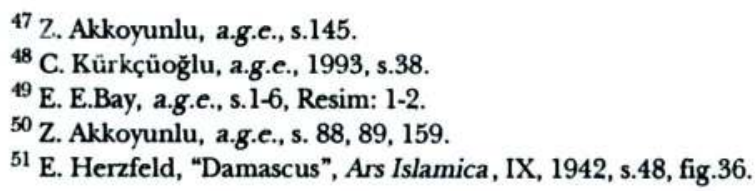


Urfa hanlarında merdiven savısı bir ile dört arasında değişmektedir. Hacı Kamil Hanı ve Bican Ağa Hanı'nın güney cephesindeki üst kata çıkışı sağlayan merdivenler "T", Şark İşhanı ve Barutçu Han'ın doğu cephesindeki merdivenler " $U$ “, Gümrük Han'ın avlu doğu kanat merdivenleri ile mescit merdivenleri " $L$ ", diğer örnekler ise düz merdivenler şeklindedir. Altlarındaki mekanlara girişi engellememek için bazı merdivenler kemerler üzerine oturmuştur. Urfa hanlarında dikkati çeken bir durum ise, Samsat Kapısı Hanı, Millet Hanı, Kumluhayat Hanı, Topçu Hanı ve Bican Ağa Hanı'nda olduğu gibi, yapıların örtü sistemlerine çıkışı sağlayan bir veya iki merdivenin yer almasıdır. Benzer bir örneğine Suriye'de Şam yakınlarındaki 1664/1665 tarihli Nebük Kervansarayı'nda ${ }^{52}$, Kilis Andibendioğlu Ali Efendi $\mathrm{Hani}^{53}$ ve Bilecik Sabunhane ${ }^{54}$ de rastladığımız bu merdivenler, Güneydoğu Anadolu Bölgesi'nde bugün de karşılaştı̆̆ımız, yaz aylarında damlarda yatma geleneğinin hanlarda da uygulandığını ve 19. yüzyıl sonu ve 20 . yüzyıl başlarında inşa edilen hanlarda, üst katların dışarıdan sağlanan girişlerle hanlardan bağımsız birimler haline dönüşmeye başladığını düşündürmektedir.

Nişler düşey dikdörtgenler şeklinde olup bazıları kemerlidir. Bir kısmı taban seviyesinde olup, içlerinde yer alan bacalarla ocak işlevi gördüğü anlaşılmaktadır. En fazla örnek Gümrük Han'da yer almaktadır. Bugün bir kısmı pencere haline dönüştürülmüş, bir kısmı ise tamamen doldurulmuştur.

Urfa hanlarında kullanılan taşlar, Urfa'nın $5 \mathrm{~km}$. batısındaki taş ocaklarından alınmıştır. Diyarbakır bölgesindeki bazalta karşılık, Urfa yöresinde açık renkli sarımsı kalker taşı mimariye hakimdir ${ }^{55}$.

Taş, düzgün kesmetaş, moloz ve kabayonu taş olarak kullanılmıștur. Düzgün kesmetaş; yapıların duvarlarında, ayaklarda, kemerlerde ve Mençek Hanı ve Barutçu Hanı'nın revak örtülerinde kullanılırken, kabayonu ve moloz taş; yapıların örtü sisteminde örgü malzennesi ve dolgu malzemesi olarak kullanılmıştur. Urfa hanlarında iki renkli taş kullanımı yalnızca Gümrük Hanı'nda görülür. Hanın doğu ve kuzey cephelerinde, üst kat doğu revakı-

${ }^{52}$ Z. Nayır, Osmanlı Mimarlığında Sultan Ahmet Külliyesi ve Sonrası(1609-1690), İstanbul 1975 , s.224-226.

${ }^{53}$ A. Dündar, a.g.e., s.380-381.

${ }^{54}$ S. Gündüz, a.g.m., s.127-129.

${ }^{55}$ A. Altun, Mardin'de Türk Devri Mimarisi, İstanbul 1971, s. 15; N. Sōnmez, "Osmanlı Mimarlığında Yapı ve Malzeme Terminolojisi Üstüne Bir Deneme”, Aslanapa Armağanı, Istanbul 1996, s.213. 
nın gerisindeki duvarlarda, bir sıra bazalt ve bir sıra küfeki taşının yatay şeritler halinde uzaması, cephelere renkli bir görünüm kazandırır. Benzer uygulamalar Gaziantep Merkez Hişva Hanı, Elbeyli Hanı ${ }^{56}$, Yeni Han ${ }^{57}$, Diyarbakır Deliller Hanı ve Diyąbakır Hasan Paşa Hanı'nda ${ }^{58}$, Şam Süleyman Paşa Hanı $(1732)^{59}$, Esat Paşa Hanı $(1753)^{60}$ ve Çakmak Han'da (18.yy. ${ }^{61}$, Halep Vezir Han'da (1682) ${ }^{62}$ da görülür. Bu tip iki renkli taş uygulamasına, Güneydoğu Anadolu Bölgesi'ndeki bütün yapı tiplerinde rastlanmasına karşılık, diğer bölgelerde yer alan hanlarda nadiren karşılaşılması, bu uygulamanın bölgede popüler olarak kullanıldığını gösterir ${ }^{63}$. Mermer, yalnızca Gümrük Hanı'nın giriş eyvanının iki yan duvarında kısmi -sarımtrak renkli- kaplama malzemesi olarak kullanılmışur (Tablo: 1).

Ahşap malzeme, Topçu Hanı ikinci kat, Barutçu Hanı üçüncü kat örtü sisteminde, Şaban Hanı'nın ikinci dönem onarımlarında inşa edilen revakların tonoz desteğinde ve hanların giriş kapı kanatlarında, pencere ve kapı kasalarında kullanılmışur.

Demir malzeme ise, yapıların giriş kapı kanatlarında kaplama malzemesi olarak, çivi, tokmak gibi elemanlarda ve pencerelerin şebekelerinde kullanılmışur.

Urfa hanlarında süsleme unsurlarına fazlaca rastlanmaz. Yalnızca Gümrük Hanı, Aslanlı Han, Bican Ağa Hanı, Topçu Hanı ve Şark İş Hanı'nda süsleme unsurlarına rastlanır. Yapıların giriş cepheleri, kapı ve pencere alınlıkları, süslemelerin yer aldığı kısımlardır ki, bunları geometrik, bitkisel, yazı ve figürlü süsleme olmak üzere dört ana grupta inceleyebiliriz (Tablo: 1).

Geometrik süsleme, yoğun olarak Gümrük Hanı'nda karşımıza çıkar. Yapının giriş eyvamı yan duvarlarında, mihrabiyelerin üzerinde kesişen altıgenlerin aralarda altı kollu yıldızlar oluşturduğu bordür; girişin üzerinde yer alan mescitin sol pencere lentosunda yatay ve dikey olarak kesişen iki şeritli örgüler ve bunların aralarda oluşturduğu sekiz kollu yıldızlardan meydana

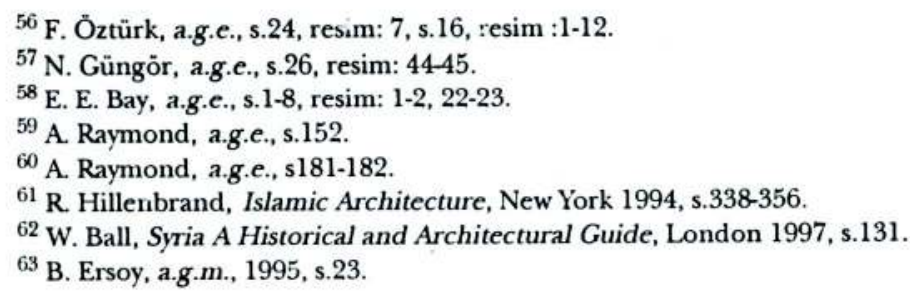


gelen kabartma bir kompozisyon yer almaktadır. Sağdaki pencere lentosunda ise, düşey eksene dik ve çapraz kırık çizgilerin eşit uzunlukta 120 derecelik açılarla kesişmesinden oluşan alt kollu yıldızlar ve altugen boşlukların meydana getirdiği kabartma süslemeler yer alır ${ }^{64}$ (Şekil:2-4). Geometrik süslemenin görüldüğü diğer bir yapı ise, Bican Ağa Hanı'dır. Yapının güney cephesinde yer alan portal alınlığında ve konsolların altında, zigzaglar ile yanyana sıralanan damla motifleri, yapıdaki geometrik süsleme unsurlarını oluşturur(Şekil: 5). Geometrik bezemenin yer aldığı diğer bir yapı Şark İşhanı'dır. Portal alınlığındaki kitabenin üzerinde, ay ve yıldız motifi işlenmiştir (Şekil: 6). Benzer uygulamaya Urfa'da sivil mimarlık örneklerinde de sıkça rastlanır ${ }^{65}$.

Bitkisel süsleme Urfa hanlarından Bican Ağa Hanı, Topçu Hanı ve Şark İşhanı'nda görülür. Bican Ağa Hanı'nın güney cephesindeki ikinci kata çıkışı sağlayan kapının üzerinde yükselen konsolları destekleyen sütuncelerin, kaide ve başlıklarında, pencere sövelerinde; üzüm salkımları, asma dalları ile palmetlerin meydana getirdiği grift yüksek kabartma bitkisel kompozisyon yer alır. Aynı kompozisyon, bugün yıkılmış olan hanın ikinci katının pencere sövelerinde de karşımıza çıkar (Şekil: 7-9). Bitkisel bezemenin görüldüğü bir diğer yapı ise, Topçu Hanı'dır. Burada Bican Ağa Hanı kadar yoğun süslemeye rastlanmasa da, yapının giriş kapısının kenarındaki sütuncelerin başlıklarında, rumi ve palmetler yer alır. Hanın ana giriş kapısı kemerinin kilit taşı ile, üst kata çıkışı sağlayan kapıların kilit taşlarında akantus yaprakları yüksek kabartma tekniğinde işlenmiştir. Şark İşhanı'nın portal alınlığında yer alan kitabenin üzerinde, ters palmet motifiyle taçlandırılmış "S" kıvrımlar ve kitabenin iki yanında yer alan 12 yapraklı çiçek rozetleri, yapıdaki bitkisel süslemeleri oluşturur.

Urfa hanlarında kitabeler dışında süsleme amacıyla yapılmış yazılara yalnızca Gümrük Hanı'nda rastlanılır. Yapının giriş eyvanı yan duvarlarında, mihrabiyelerin üzerinde geometrik bordürlerin arasında, Kur'an'dan alınan ayetlere yer verilmiştir.

Figürlü süslemeye, Urfa hanlarından yalnızca bugün yıkılmış olan Aslanlı Han ve Şark İşhanı'nda rastlamaktayız. Aslanlı Han'dan getirilip Urfa

${ }^{64}$ C. Kürkçüoğlu, Şanlıurfa İslam Mimarisinde Taş Süsleme, ( S.Ü. Sosyal Bilimler Enstitūsü, Arkeoloji ve Sanat Tarihi Anabilim Dah, Sanat Tarihi Bilim Dalı, Yaynnlanmamış Doktora Tezi), Konya 1998, s.71.

${ }^{65}$ Z. Akkoyunlu, a.g.e., s.130, resim: 135 . 
Müzesi'nde muhafaza edilen iki aslan kabartması dikkat çekicidir. Olasılıkla hanın giriş cephesinde yer alan kabartmalardan dolayı, han bu isimle anılmış olmalıdır. Profilden, başlar geriye dönük olarak resmedilen aslanlar, birer zincir ile bağlıdır. Stilize edilmiş yüz hatları bulunan aslanların vücut tüyleri, kabaca işlenmiştir (Şekil: 10-11). Aslan figürlerinin yer aldığı diğer bir han ise, Sivas Taş Han'dır. Burada giriş cephesinin üzerinde karşılıklı yerleştirilmiş iki aslan figürü bulunmaktadır. Bu figürler, arka ayakları üzerinde oturur biçimde tasvir edilmiştir. Figürlü bezemenin yer aldığı diğer bir han, Kilis Baytazzade Hanı(16.yy)'dır. Hanın avlu güney kanadında yer alan mekanın kemer köşeliklerinde kabartma iki pars figürü (?) işlenmiştir. Sağa doğru profilden yürür vaziyette, baş cepheden resmedilmiş olan parsların yüzü, stilize edilmiştir ${ }^{66}$.

Araşurmalarımız, Osmanlı yönetimine geçtiği 1517 tarihinde iki kervansaray bulunan kentte, han sayssının 1649 tarihinde altyya, 1867 tarihinde yediye, 1883 tarihinde dokuza, 1891 tarihinden önce 11'e ve 1894 yllında ise 32'ye ulaştuğı anlaşılmaktadır. 1927 yılında kentteki han sayısının 20'ye inmesi, 19. yüzyıl sonunda yoğun bir ticaret potansiyeline sahip olan kentin ticari hayatunda da gerileme olduğunu gösterir.

19. yüzyıla kadar kentin ticari hayatunın çekirdeğini, kent merkezinde yer alan Gümrük Hanı ve bedesten etrafinda gelişen ticaret bölgesi oluştururken; bu yüzyıldan sonra kentin kuzeyinde çok sayıda han inşa edilmesi, ticari hayatın şehrin kuzeyine, sur dışına doğru gelişme gösterdiği anlaşılmaktadır.

Plan tiplerini belirleyebildiğimiz hanların tamamı bir avlulu olarak inşa edilmiştir. İnşa edildiği arazinin kadastral durumuna göre şekillenen hanlar, çoklukla asimetrik plana sahiptir.

Hanlar, kat durumlarına göre tek katlı, kısmen iki katlı, iki kath ve kısmen üç kath olmak üzere dört alt gruba ayrılmaktadır. Bu güne değin yapılan araşturmalar, tek katlı ve avlulu şehir içi han örneklerinin oldukça az görüldüğünü göstermiştir. Bu nedenle Urfa'da tek katlı ve avlulu han tipinden üç örnek bulunması önemlidir. Kısmen iki kath hanlar ve kısmen üç katlı hanlar da tek katlı hanlar gibi şehir içi hanları arasında az görülen bir plan

${ }^{66}$ A. Dündar, a.g.e., s.366-371. 
tipidir. Kısmen üç katlı hanlardan Gümrük Han, bu plan tipinin bugüne değin bilinen en erken tarihli örneğini yansıtması açısından önemlidir.

Urfa hanlarında örtü sisteminde genellikle sivri beşik tonoz ve çapraz tonoz tercih edilmiştir. Barutçu Han ve Mençek Hanı'nın revak örtüsünde düz salma taş kullanılması ise, bu hanlara ait bir özelliktir. Yapılarda, ahırların hep avlu kanatlarında yer aldığı görülmektedir. Urfa hanlarının bazılarında, örtü sistemine ve kısmi ikinci katlara çıkışı sağlayan bir yada iki merdiven bulunması, Güneydoğu Anadolu Bölgesi hanları dışında, diğer bölgelerde rastlanmayan bir özelliktir. Bu merdivenlerden dolayı hanların üzerinin, (bölgede sivil mimarlık örneklerinde sıkça karşılaşılan) yazları uyumak için kullanıldığını düşünmemize neden olmaktadır. Avlu etrafında yer alan mekanların, bazı hanlarda eyvan şeklinde avluya açılması, Güneydoğu Anadolu Bölgesi hanları dışında, diğer bölgelerdeki hanlarda rastlanılmaz. Kumluhayat Hanı'nda avlu cephesinde görülen, bir eyvan ve iki yanda eyvan ile bağlantılı iki küçük mekan şeklindeki düzenleme, Suriye Bölgesi hanlarında karşımıza çıkan bir özelliktir.

Hanlarda taşıyıcı sistemlerde düzgün kesmetaş kaplamalı moloz taş dolgu, örtü sistemlerinde ise moloz taş ve kabayonu taş malzeme kullanılmıştur. Az olsa da ahşap tavan ve çatılara da yer verilmiştir.

Hanlarda süsleme unsurlarına az rastlanmaktadır. Var olan süslemeler portal ve portalin yer aldığı cephelerde yoğunlaşmıştur. Urfa'da sivil mimarlık örneklerindeki yoğun süslemeye karşıllk, anıtsal yapılarda süslemeye ender rastlanması ilgi çekicidir.

Urfa hanları, genel plan şemaları açısından Osmanlı hanlarının özelliklerini yansıtırken; mimari detaylar, malzeme, süsleme ve yapı elemanlanı ile de bölgesel özellikleri ön plana çıkarır. İki renkli taş malzemenin kullanımı, tercih edilen örtü sistemleri, dilimli ve kaş kemerler, süslemenin sade özellikleri bölgesel etkileri yansıtur.

Tespit ettiğimiz 32 handan 11 tanesinin günümüze gelmiş olması, kültür varlıklarımızın ne kadar hızlı bir şekilde yok olduğunu göstermektedir. Bu hanların büyük bir çoğunluğunun yakın zamanlarda yok edildiğini düşünürsek, bu tahribatın gün geçtikçe daha da yoğunlaştuğı görülmektedir. 


\section{Adil Özme}

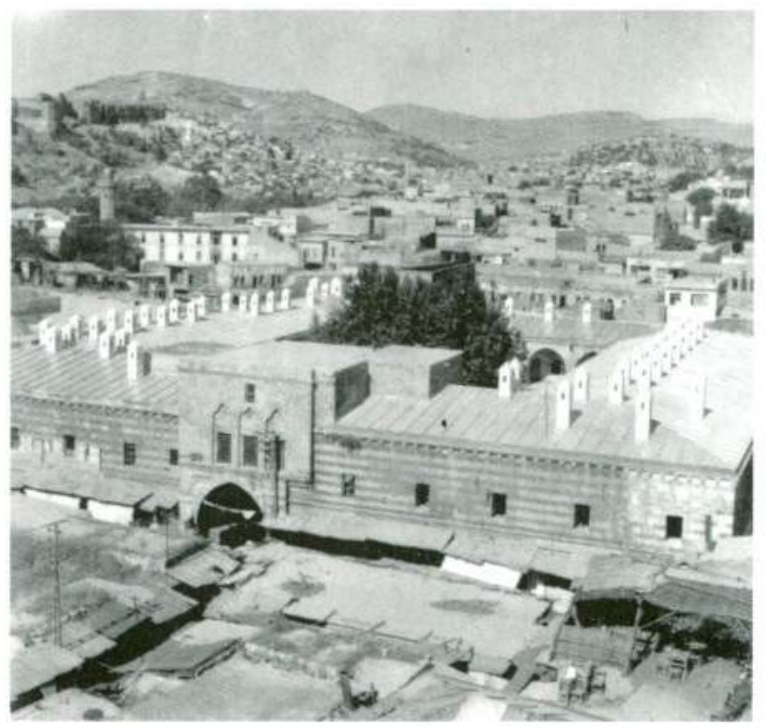

Res. 1 - Gümrük Ham genel görünüm.

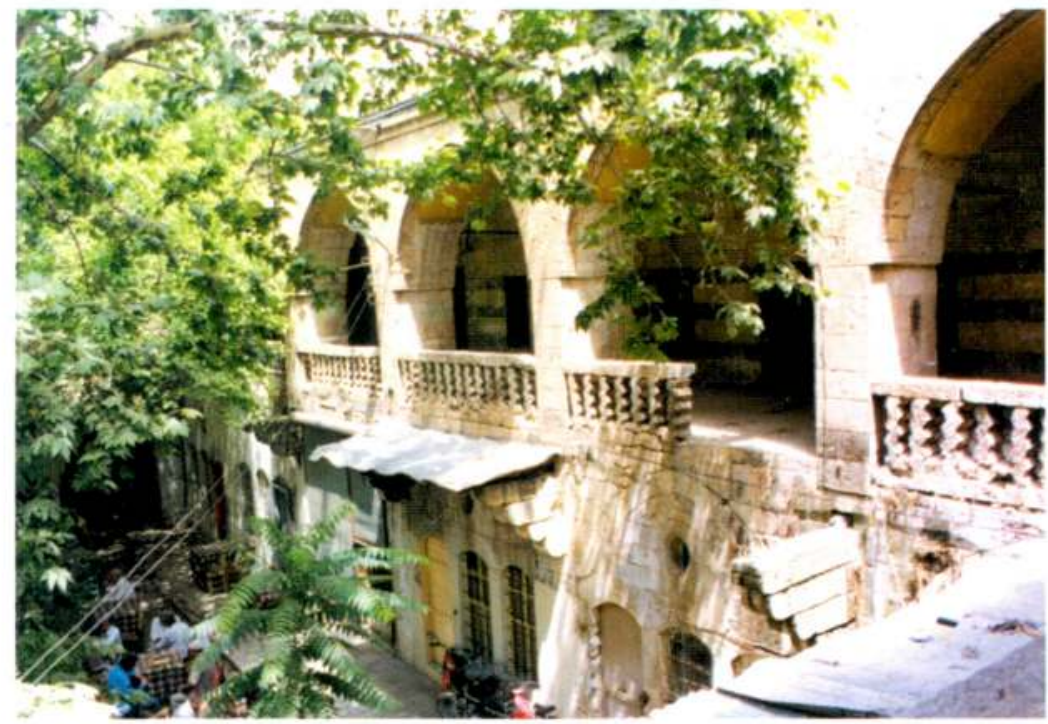

Res. 2-Gümrük Hanı, avlu kuzey revakları. 
Adil Özme

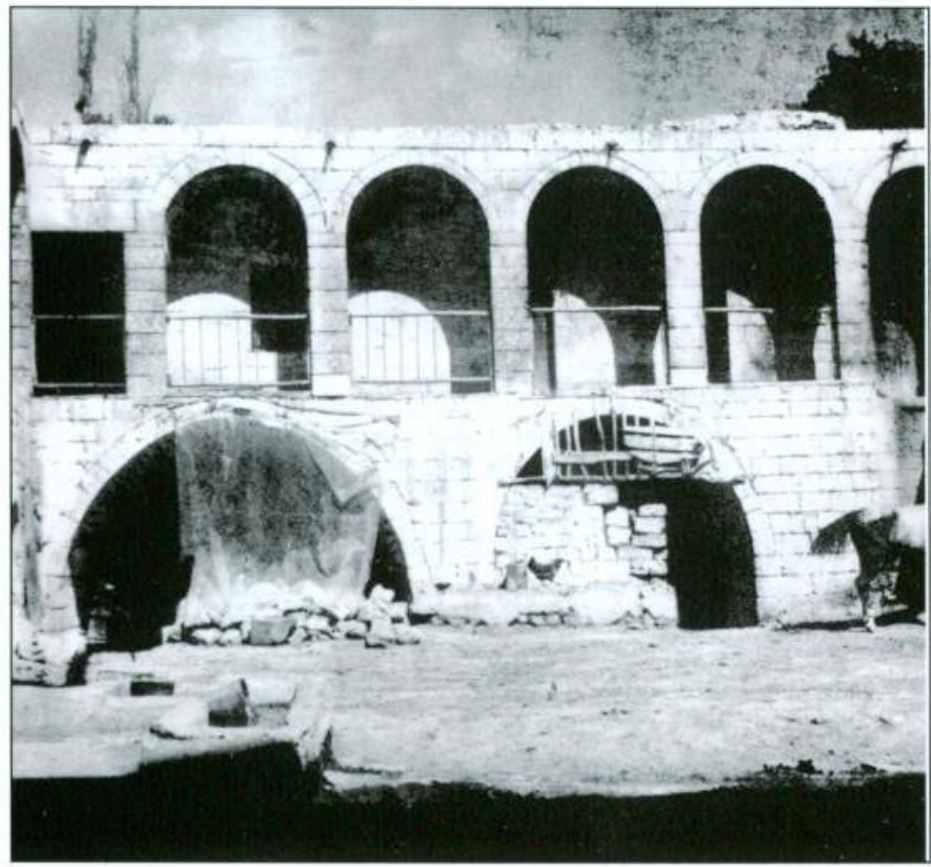

Res. 3 - Șaban Han avlu.

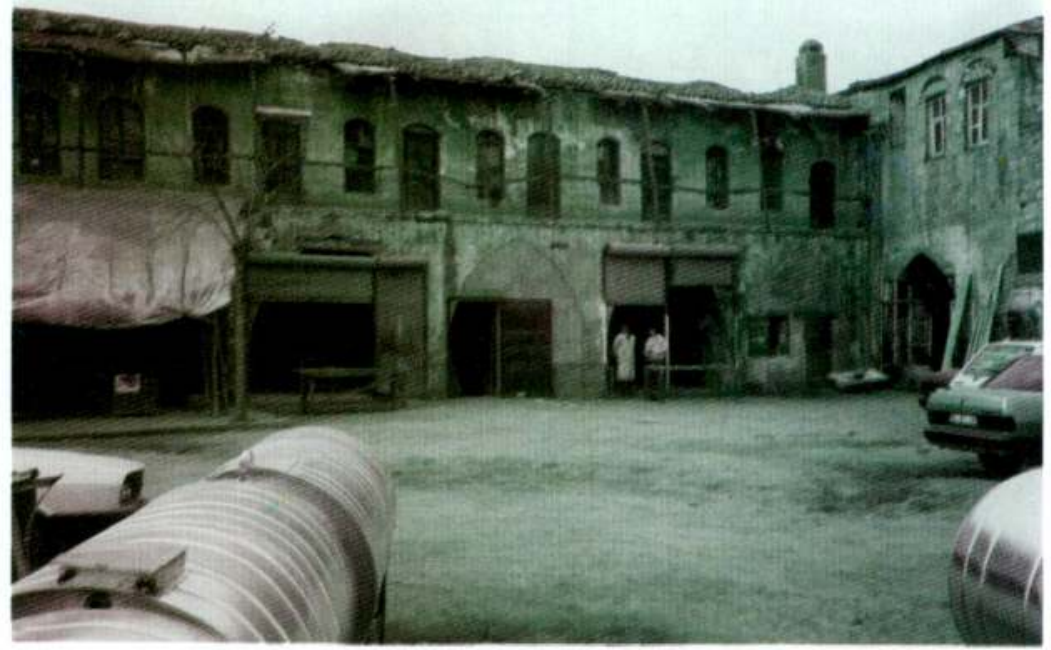

Res. 4 - Topçu Hanı avlu. 


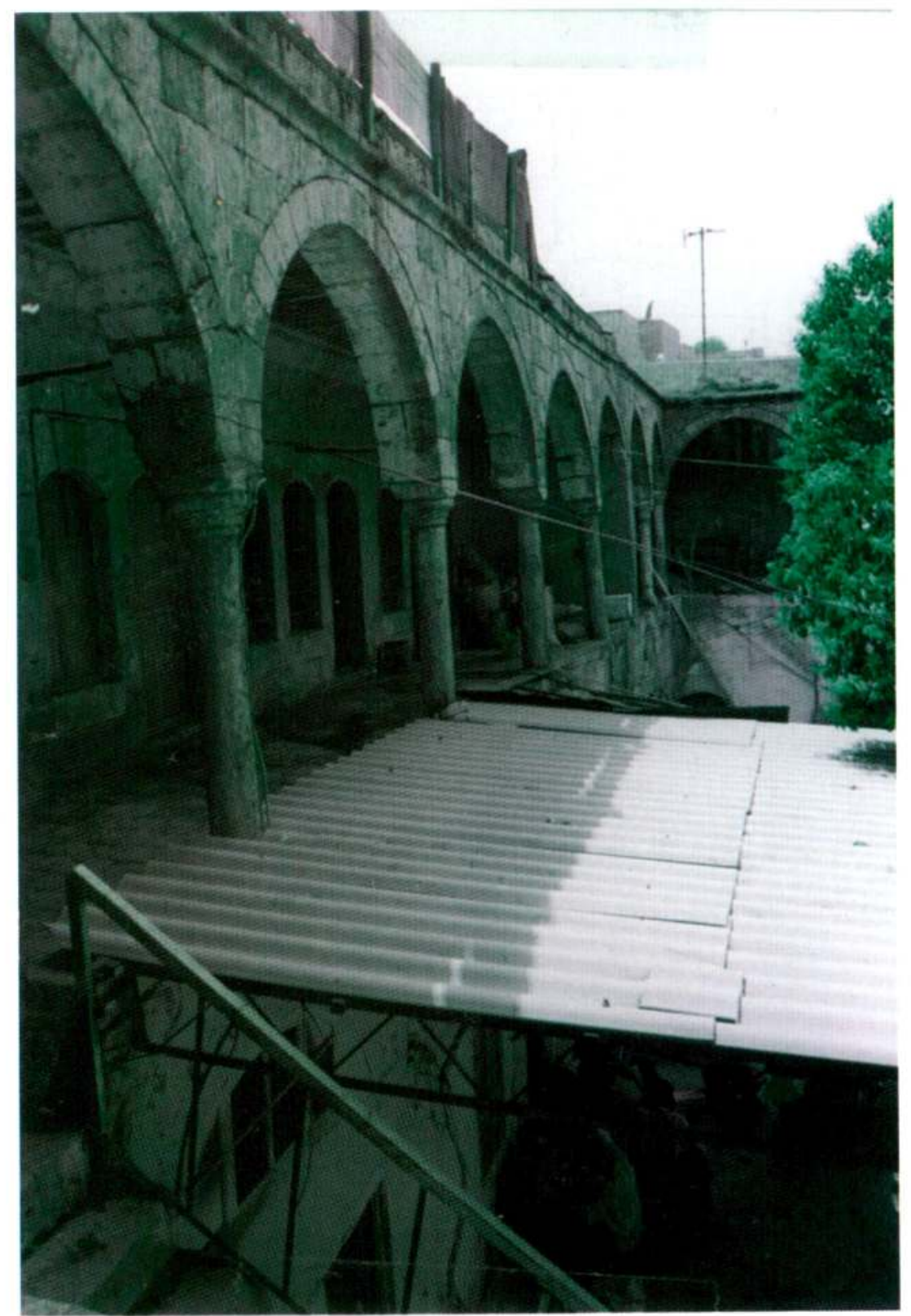

Res. 5 - Barutçu Hanı ikinci kat revaklan. 
Adil Özme

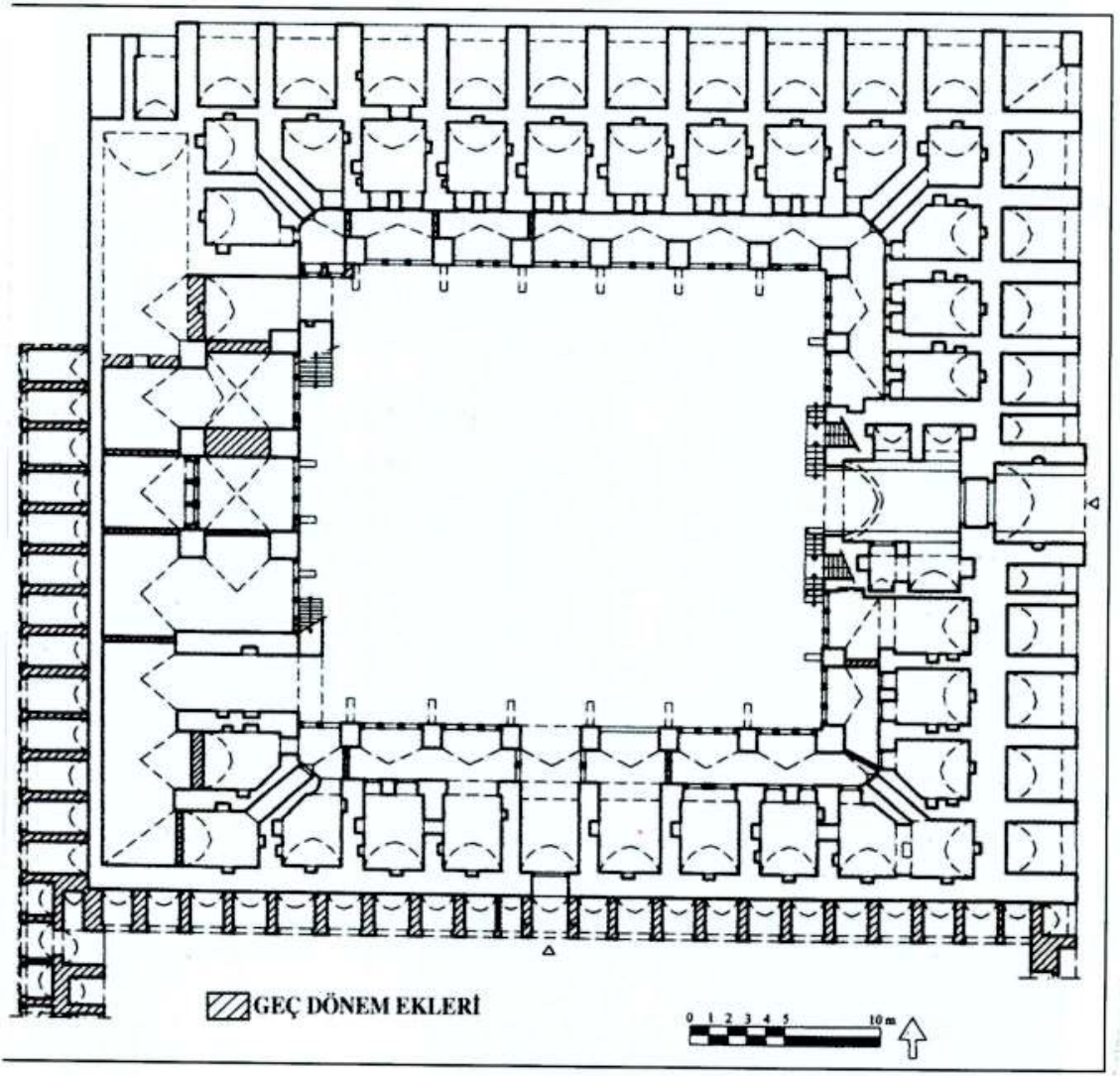

Plan 1 - Gümrük Hanı alt kat rölöve planı. 
Adil Özme

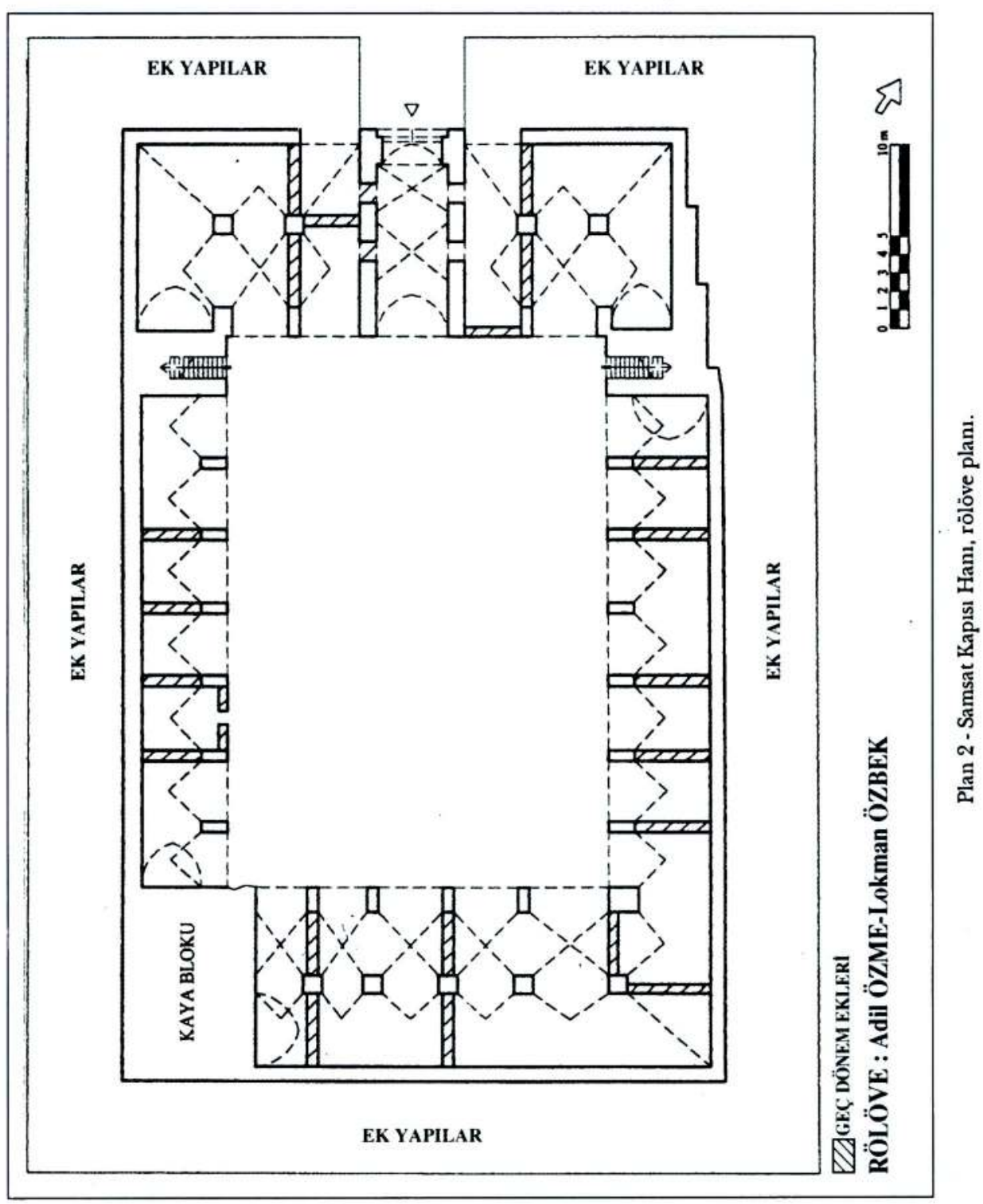




\section{Adil Özme}

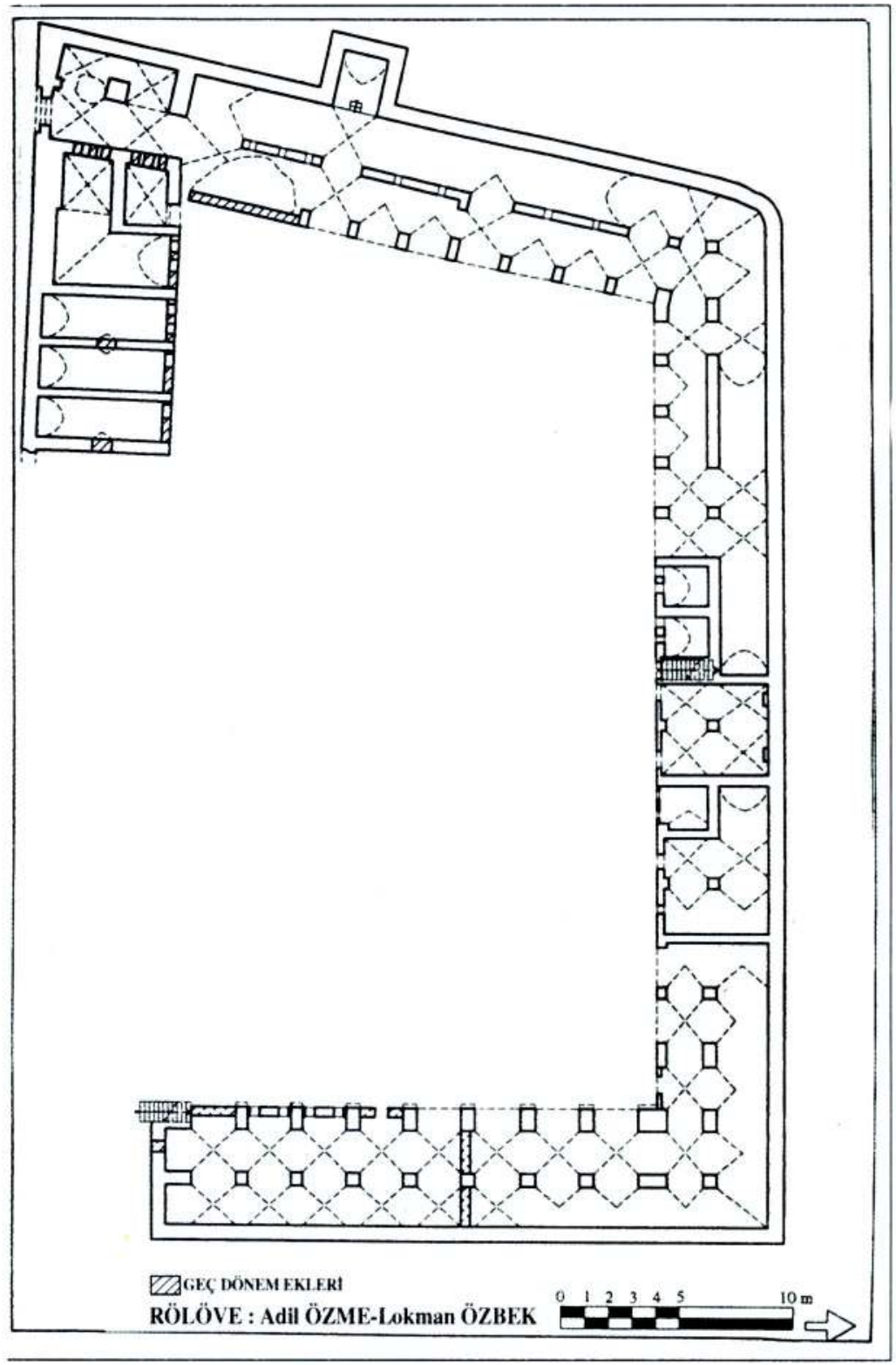

Plan 3 - Millet Hanı rŏlōve planı. 
Adil Özme

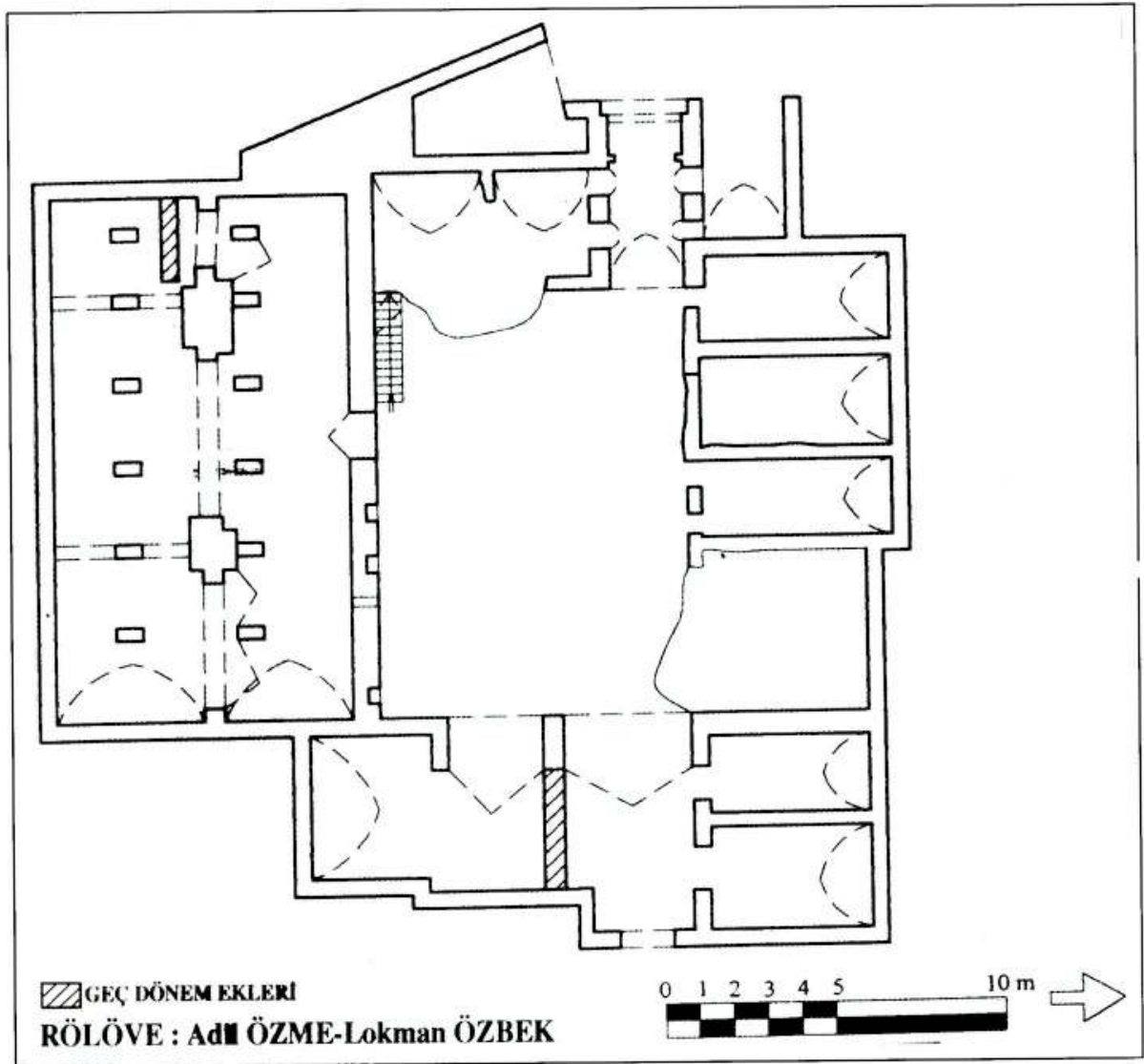

Plan 4 - Millet Ham rölöve planı. 


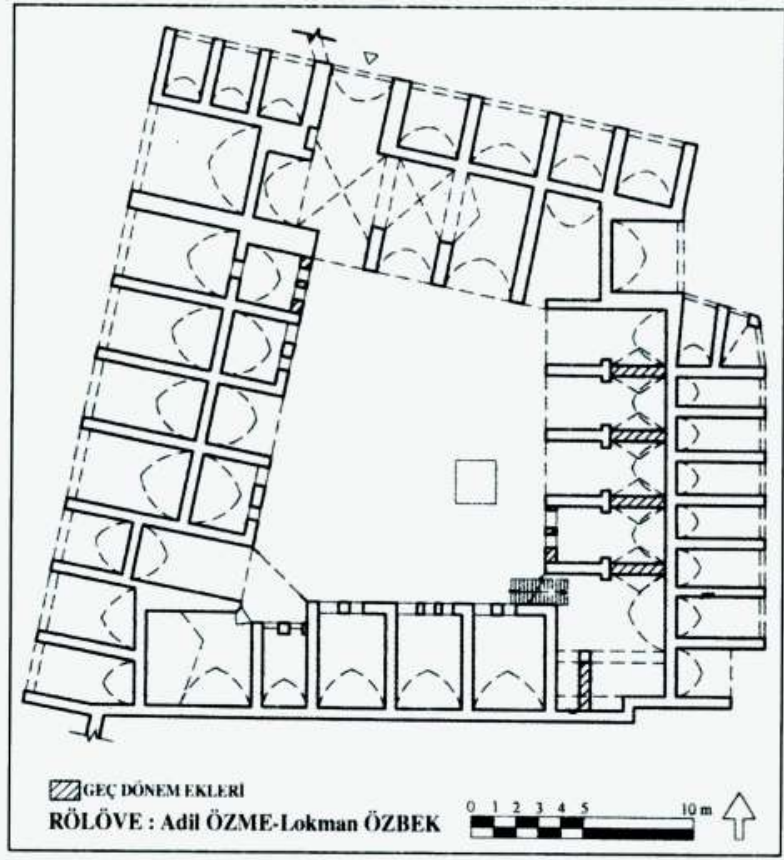

Plan 5 - Mençek Han alt kat rölōve plan.

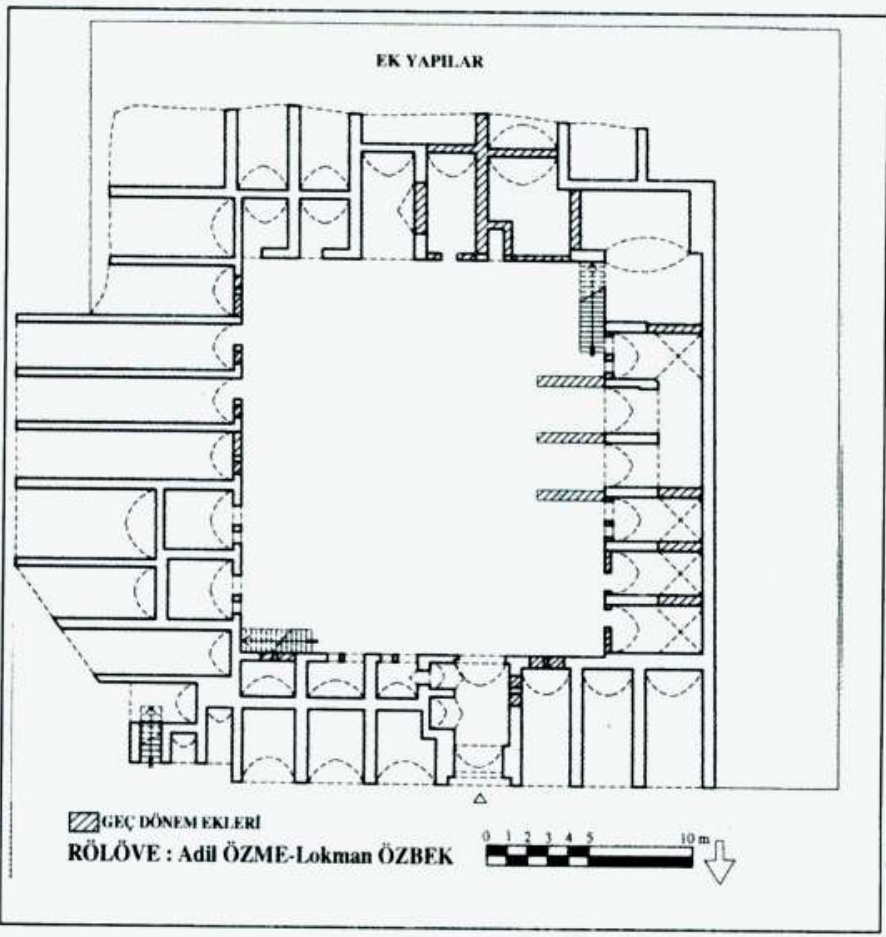

Plan 6 - Barutçu Hanı alt kat rölöve planı. 
Adil Özme

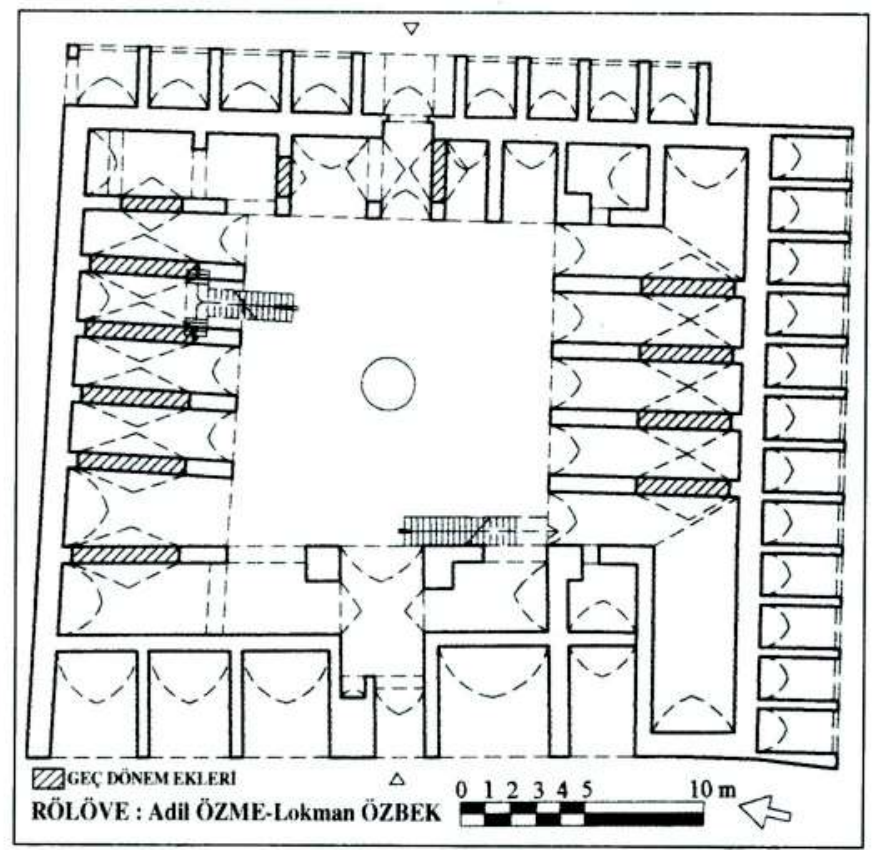

Plan 7 - Hacı Kamil Hanı alt kat rōlōve planı.

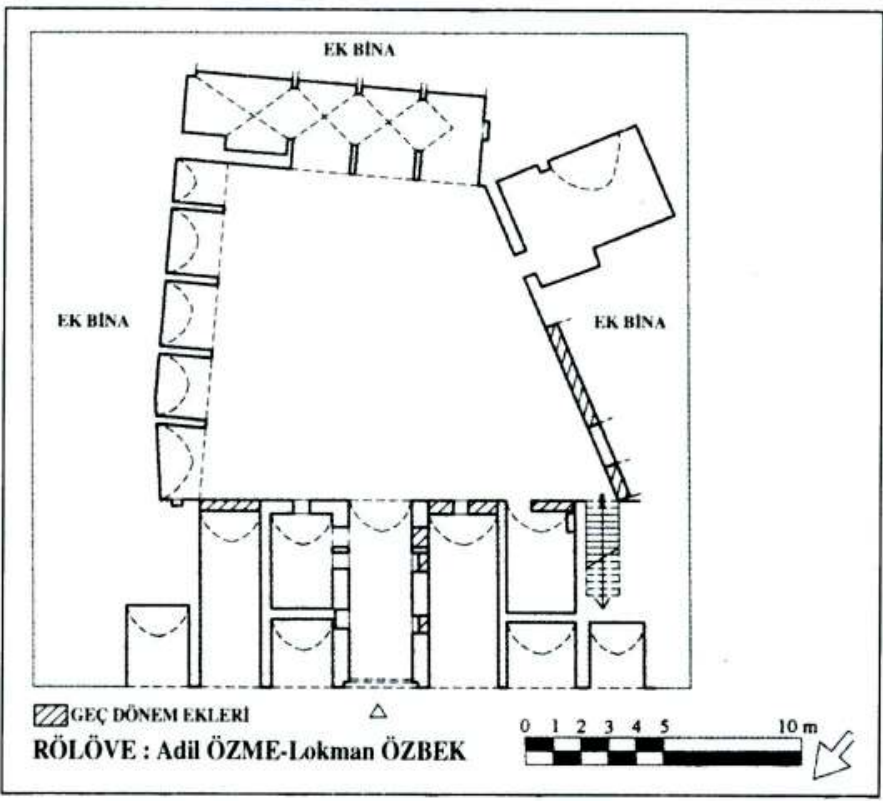

Plan 8 - Kumluhayat Hanı rōlöve planı. 
Adil Özme

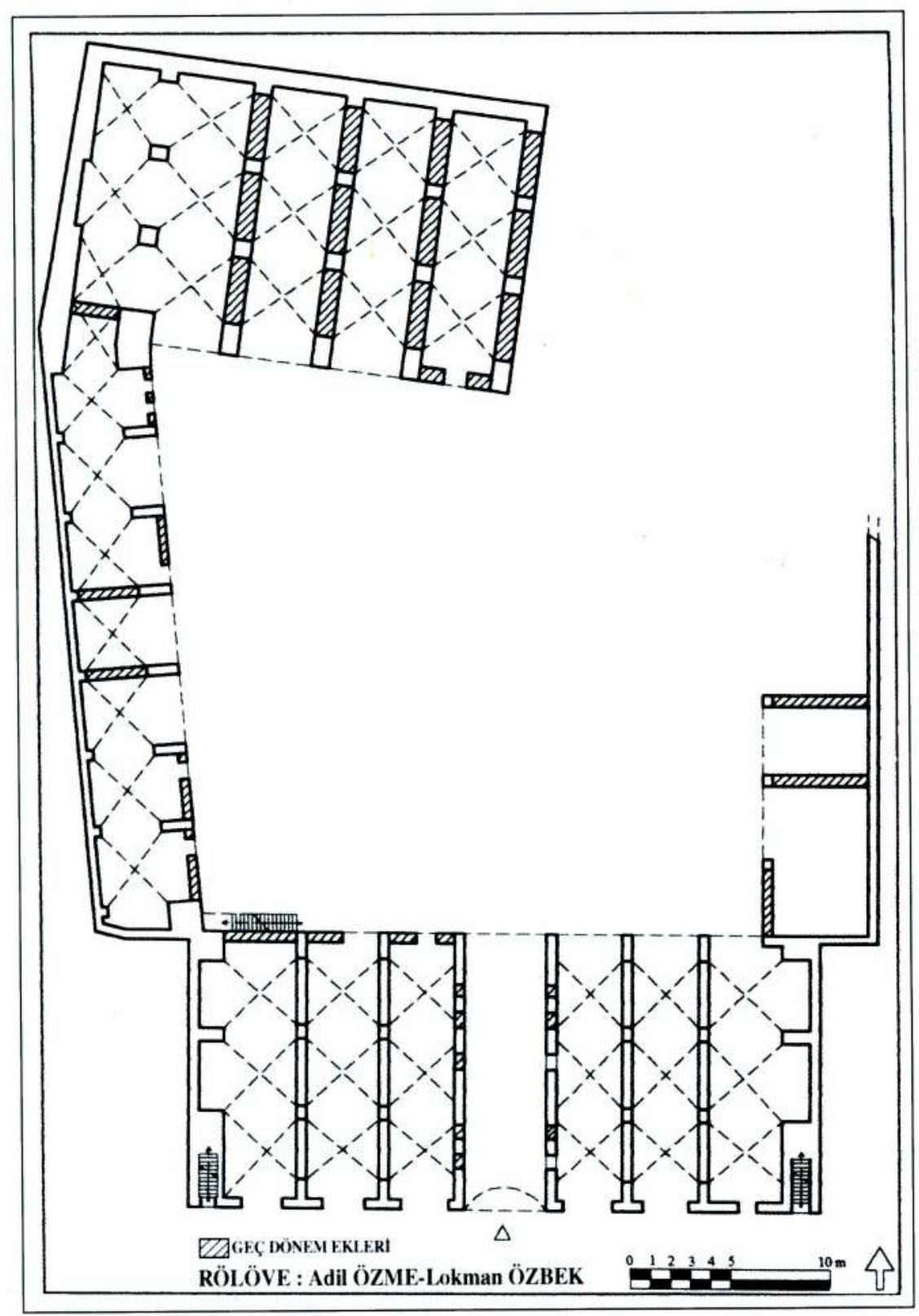

Plan 9 - Topçu Hanı rölöve planı. 


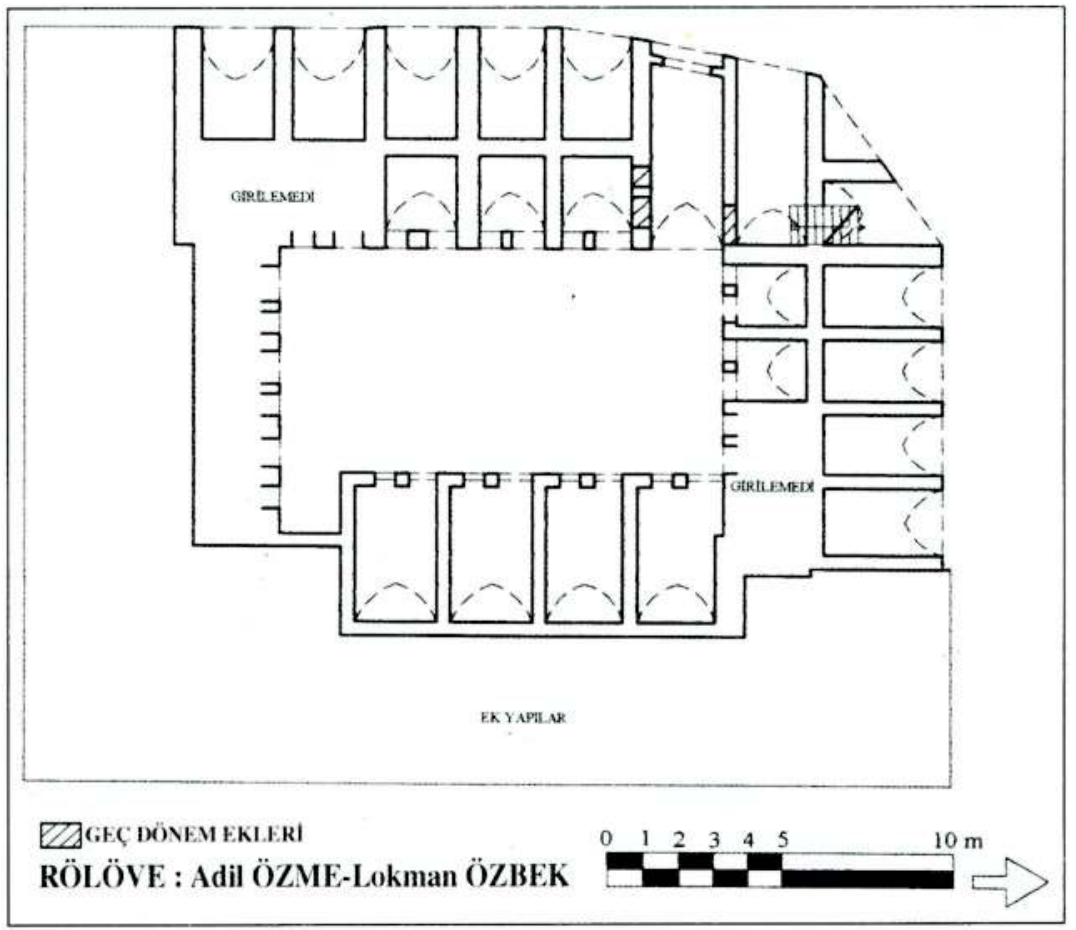

Plan 10 - Şark İ̧ Ham rölöve planı.

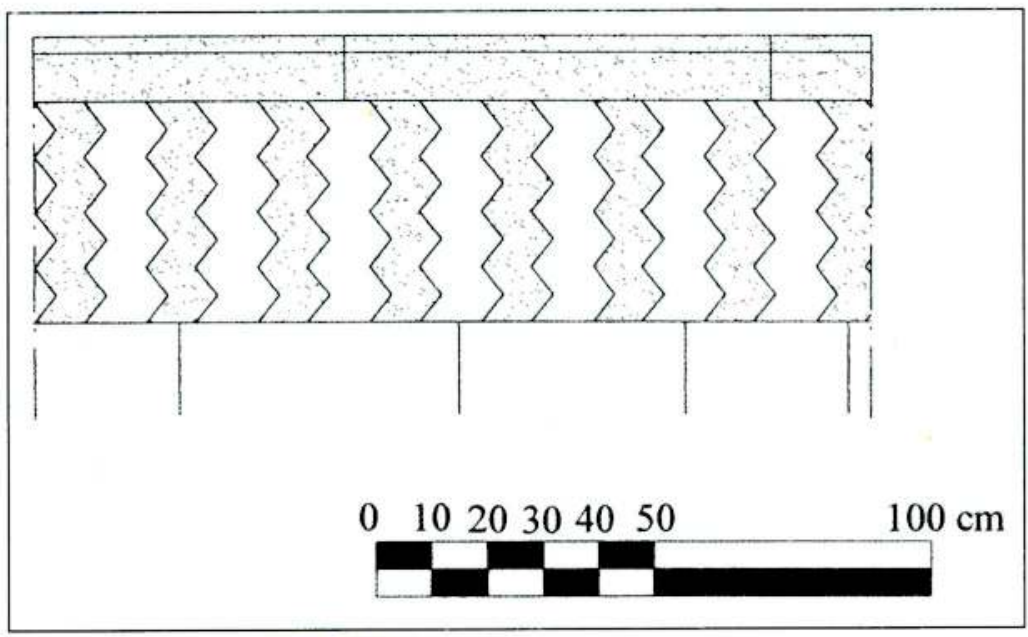

Şekil 1 
Adil Özme

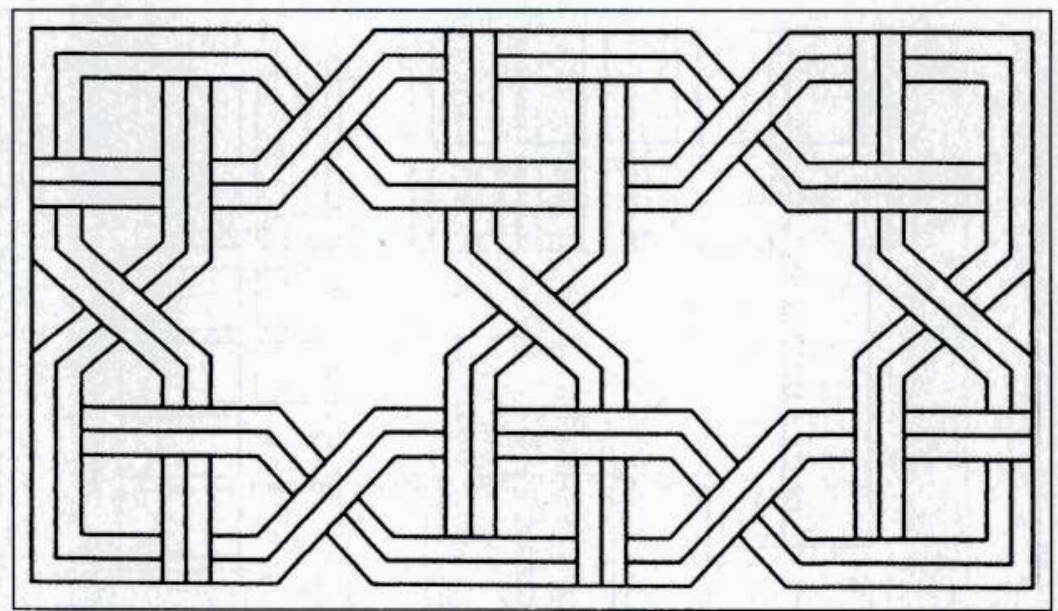

Şekil 2 - Gümrük Han, mescit penceresinin lentosundaki süsleme (Kürkçưoğlu'ndan).

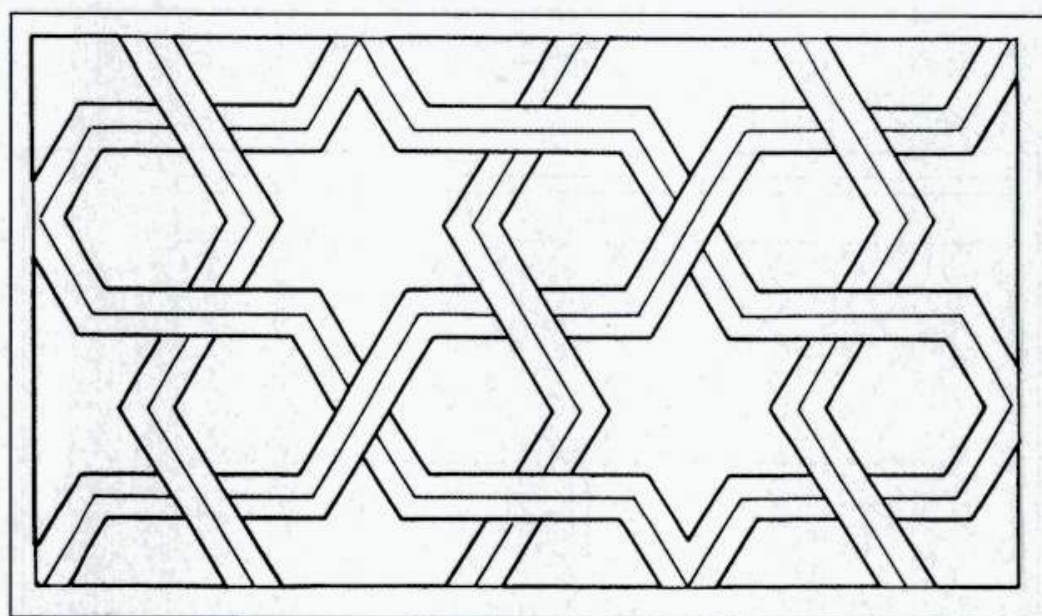

Şekil 3 - Gümrük Hanı, mescit penceresinin lentosundaki süsleme (Kürkçüoğlu'ndan). 


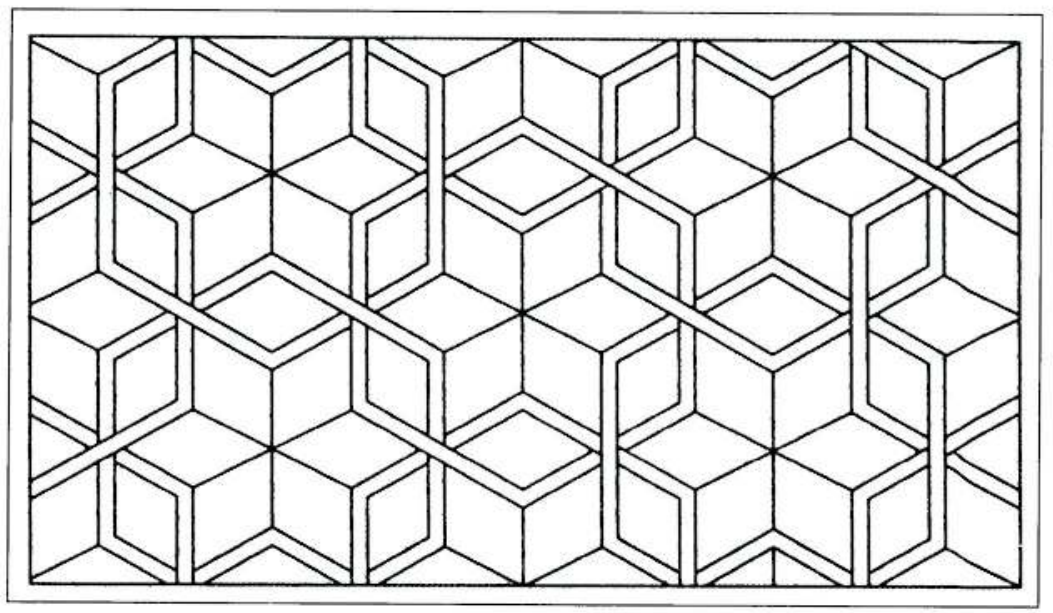

Şekil 4 - Gümrük Hanı, giriş eyvanı duvarlanındaki süsleme

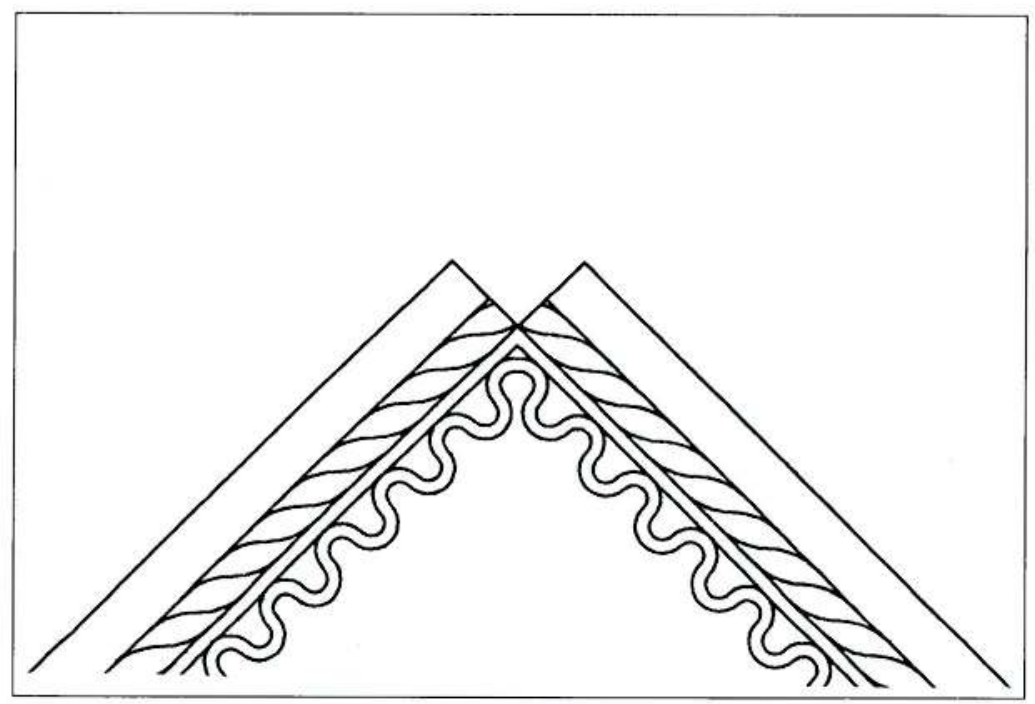

Şekil 5 - Bican Ağa Hanı, güney cephedeki portal alınlığı süslemeleri. 


\section{Adil Özme}

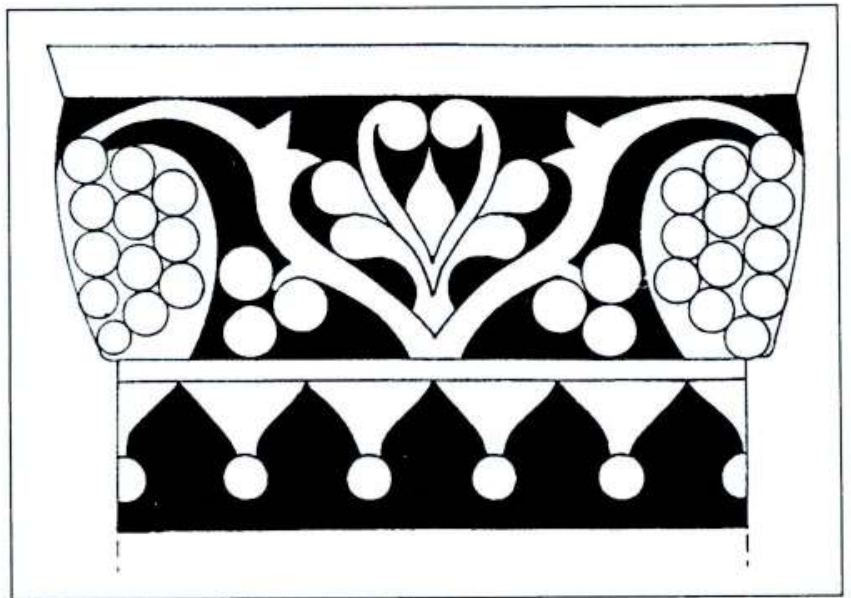

Şekil 6 - Bican Ağa Hanı, güney cephedeki portal sütunce başlı̆̆ı (Kürkçüoğlu'ndan).

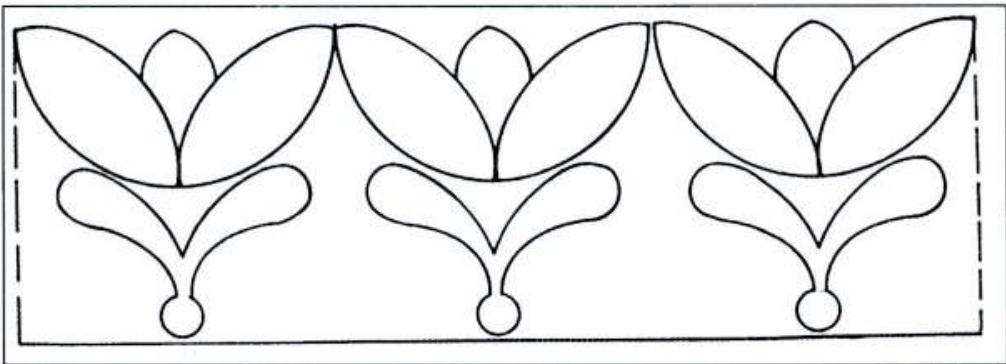

Şekil 7 - Bican Ağa Ham, güney cephedeki portalde yer alan palmet dizisi (Kürkçüoğlu'ndan).

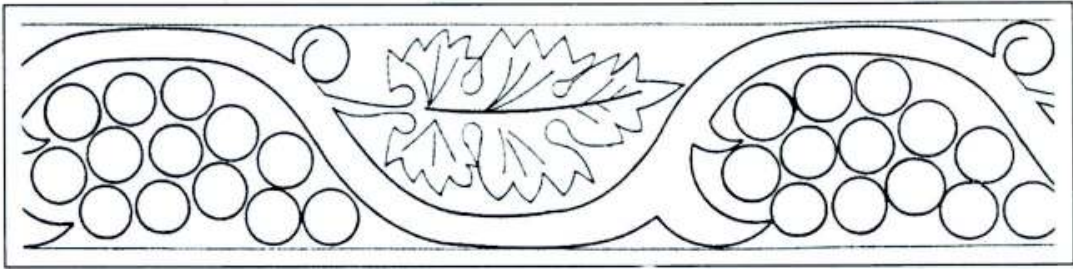

Şekil 8 - Bican Ağa Hanı, güney cephedeki portalde yer alan asma dalları ve üzüm salkumlan (Kürkçüoğlu'ndan). 


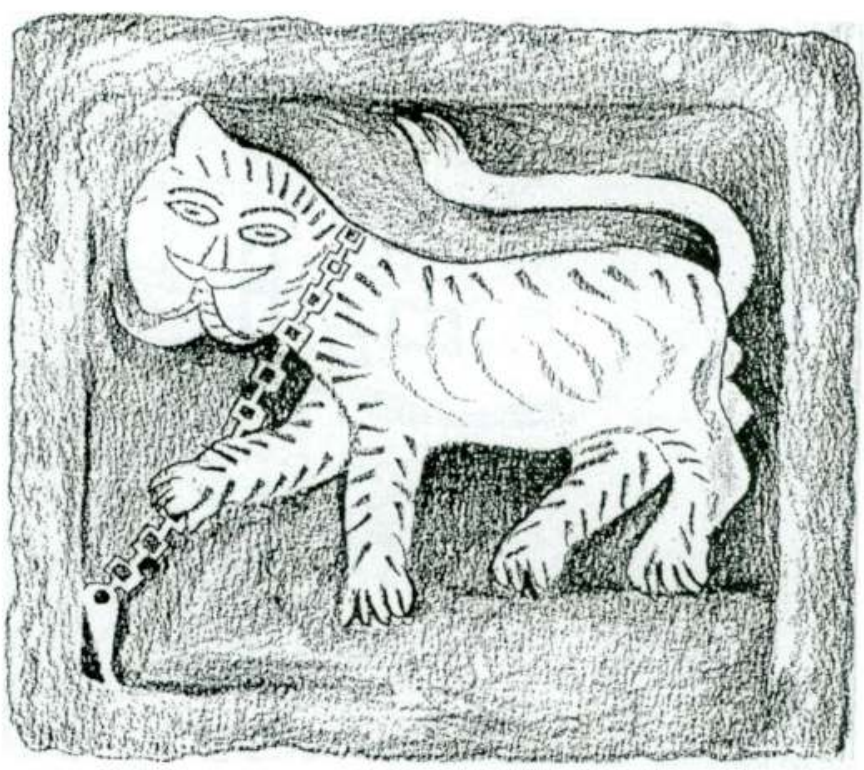

Şekil 9 - Uıfa Müzesi'ndeki Aslanlı Han kabartması (Kürkçüoğlu'ndan).

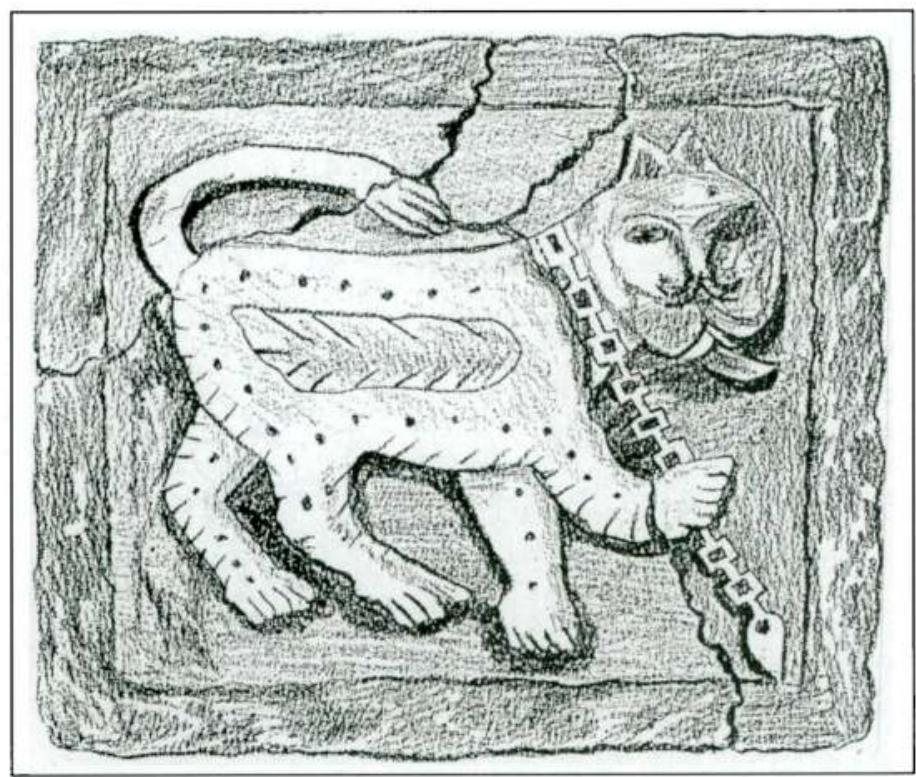

Şekil 10 - Urfa Müzesi'ndeki Aslanlı Han kabartması (Kürkçüoğlu'ndan). 


\section{Adil Özme}

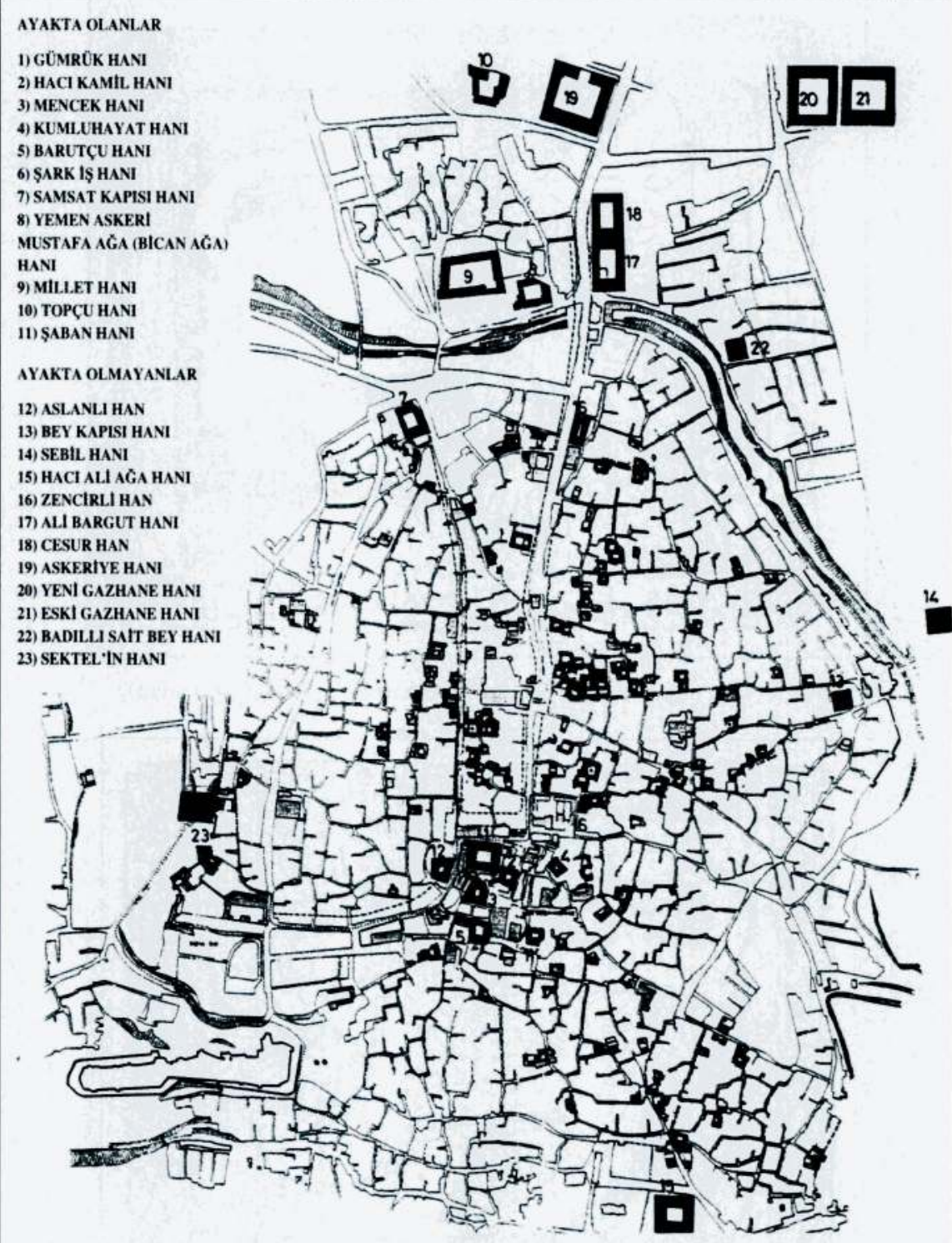

Harita: 1/5000 ölçekli harita üzerinde hanların konumu. 


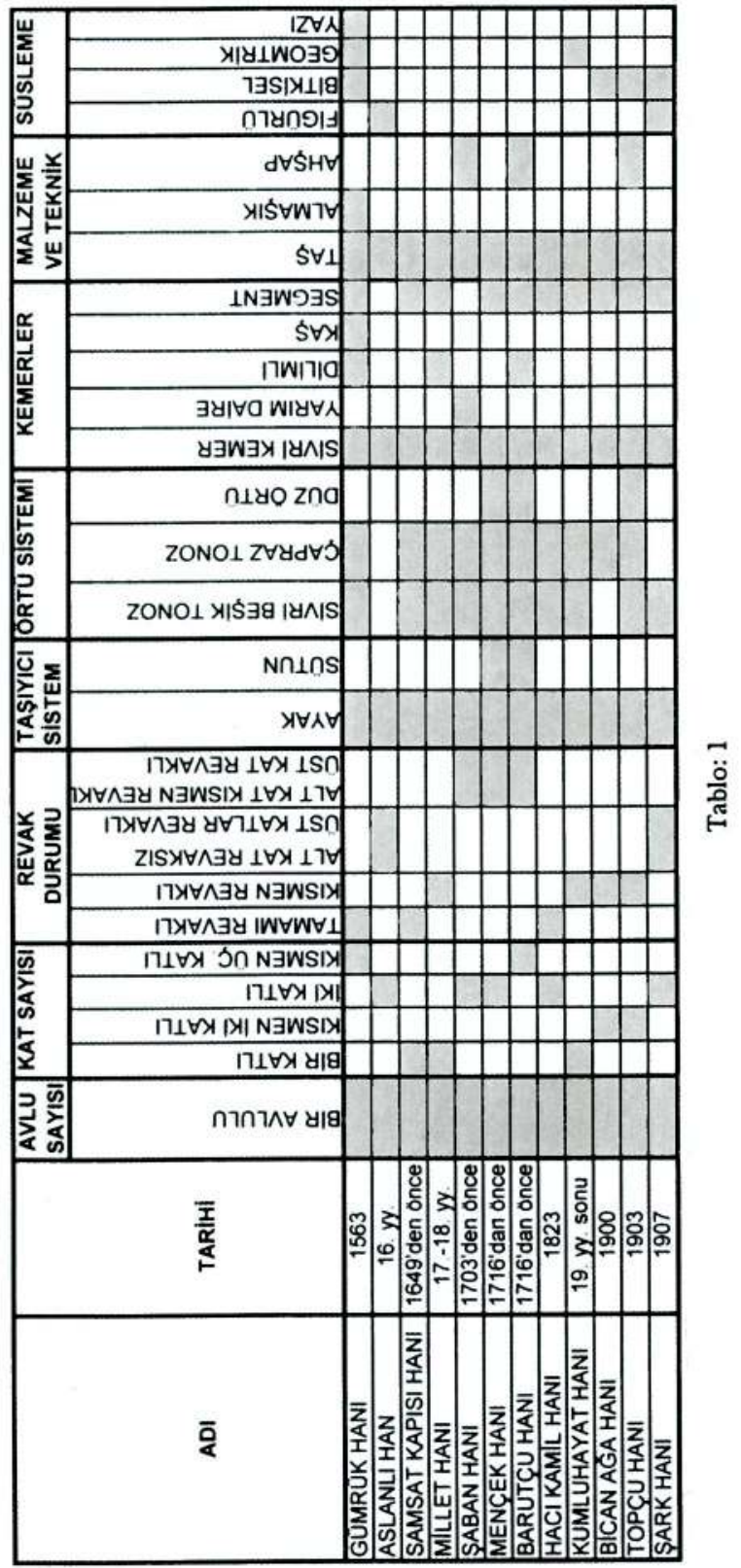


